\title{
Primjena metode fraktalnog crteža u socijalnopedagoškom radu
}

\author{
Valentina Hundrić \\ CZSS Zagreb — Podružnica Trešnjevka, Zagreb, Hrvatska \\ E-mail:dagaz75@gmail.com
}

\begin{abstract}
Sažetak
U ovom je radu cilj prikazati kreativni aspekt socijalnopedagoškog rada mogućnošću primjene metode fraktalnog crteža u radu s djecom i mladima s problemima u ponašanju, kao i stručnjacima koji rade s njima, primarno predstavljanjem Projekta "Linije i boje otkrivaju mene" namijenjena djeci i mladima u institucijskom tretmanu i odgojiteljima koji rade $s$ njima radi preveniranja rizičnih aktivnosti i jačanja kapaciteta za lakše nošenje sa stresnim situacijama. Tijekom Projekta, za primjenu metode educirano je 80 polaznika, djece i mladih s problemima u ponašanju te stručnjaka koji rade s njima, od kojih je većina sudionika metodom samoprocjene iskazala pozitivne učinke osobnog iskustva primjene metode, poput osjećaja opuštenosti i dobra raspoloženja.

Metoda fraktalnog crteža inovativna je i kreativna metoda bazirana na principima art-terapije, Brain Gyma, kromoterapije, grafomotoričkih vježba i neuroznanstvenih koncepata, koja je značajna zbog svoje jednostavnosti, opuštajućeg učinka na crtača te djelovanja na razvoj i jačanje kognitivnih funkcija, odnosno pažnje, koncentracije, kreativnosti, samopouzdanja i motivacije za rad.

Metoda polazi od činjenice o povezanosti motorike ruku i čovjekovih psihofizioloških stanja i posjeduje dijagnostički i terapeutski potencijal. Tehnologija izrade fraktalnog crteža vrlo je jednostavna i sastoji se od spontanog crtanja jedne neprekinute linije zatvorenih očiju i bojenja polja nastalih presijecanjem linija. Metoda je lako primjenjiva u individualnom ili skupnom radu, nevezano za dob ili prethodno crtačko iskustvo.
\end{abstract}

Ključne riječi: fraktalni crtež, razvoj kreativnih i kognitivnih potencijala, rizična ponašanja, prevencija

\section{Uvod}

Tijekom svojega radnog iskustva socijalnog pedagoga u sustavu socijalne skrbi zamijetila sam da velik broj djece, koja manifestira probleme u ponašanju, posjeduje izrazite kreativne potencijale osobito za likovnu umjetnost, međutim, iste najčešće ne razvijaju i ne koriste se njima u dovoljnoj mjeri. Uzimajući u obzir njihov osjećaj neuspješnosti i negativnu sliku koju najčešće imaju o sebi, upravo razvijanje kreativnog potencijala na području njihova interesa može biti značajno uporište i podržavajući čimbenik u socijalnopedagoškom radu s njima. Izuzev navedenoga postoje i mnoge druge dobrobiti, što potvrđuju brojni autori koji u svojim istraživanjima i radovima ističu mogućnosti pozitivna djelovanja art-terapije ${ }^{1} \mathrm{u}$ tretmanu djece i mladih s problemima u ponašanju.

Darnold (2016) u svojem radu zaključuje o značajnu djelovanju kreativnih i ekspresivnih tehnika na reduciranje stresa i napetosti, ali i stvaranju sigurna okruženja, razvijanja osjećaja zajedništva

1 Art-terapija je forma neverbalnog izražavanja misli i osjećaja, a temelji se na ideji da se različitim medijima iz područja različitih umjetnosti kreativnim procesom liječi i djeluje na kvalitetu života (American Art Therapy Association, 1996, prema Škrbina, 2013). 
te osnaživanja i razvoja sposobnosti djece i mladih u riziku. $U$ radu navodi neke od studija, npr. istraživanja provedena na populaciji djece i mladih u riziku, u kojemu zaključuje da je bojenje mandala kružnoga ili četvrtastoga geometrijskog dizajna, odnosno dovršavanje zadane strukturirane i kompleksne forme djelovalo na smanjenje anksioznosti sudionika dovodeći ih u meditativno, opuštajuće stanje (Curry i Kasser, 2005), odnosno studija koja je povezala učinkovitost crtanja mandala i smanjenja simptoma ADHD-a, nalazeći da je crtanje mandala pridonijelo povećanju sposobnosti održavanja pažnje i smanjenju impulzivnosti sudionika. Zaključili su i da navedena aktivnost može pozitivno djelovati na poboljšanje sposobnosti donošenja odluka i dovršenje započetih zadataka (Smitheman-Brown i Church, 1996).

Weiner (2012) je, u provedenom istraživanju s djecom u dobi od 9 do 10 godina pretežno iz latinoameričkih obitelji nižega socioekonomskog statusa, potvrdila značajan utjecaj primjene Mindful art programa baziranih na art-terapiji i Mindfulnessu ${ }^{2}$ na reduciranje stresa i jačanje suosjećanja prema sebi i drugima. $U$ jednom od istraživanja koje Weiner navodi u radu, provedenom s djecom i adolescentima u riziku, utvrđeno je da su programi bazirani na kombinaciji art-terapije i Mindfulnessa pokazali veću učinkovitost nego oni u kojima se prakticirao isključivo Mindfulness. Kao razlog tomu ističe se veća sigurnost koju su djeca osjećala tijekom primjene kreativnih programa te su ih doživjela zabavnijim i aktivnije sudjelovala u njima. Djeca su lakše usvajala vještine Mindfulnessa poput samosvjesnosti, vlastitih misli i emocija bez prosuđivanja uz aktivnosti koje su procijenile zabavnim, što je pridonijelo učinkovitijoj regulaciji i izražavanju emocija, učinkovitijem nošenju s problematičnim situacijama te jačanju socijalnih vještina, što su potvrđivali i njihovi roditelji (Coholic, 2011).

Zanimljivo istraživanje o učinku integrativne art-terapije provedeno je i u Litvi, u jednoj korekcijskoj ustanovi za djevojke, počiniteljicama kaznenih djela u dobi od 14 do 16 godina, koje je pokazalo statistički značajan rezultat kad je riječ o smanjenju frekvencije agresivnog ponašanja, odnosno porastu frekvencije javljanja prosocijalnih ponašanja kod delinkventnih djevojaka koje su sudjelovale u Programu, u odnosu na kontrolnu skupinu (Koiv i Kaudne, 2015).

U navedenim primjerima zamjećuje se značajan pozitivan učinak kreativnih tehnika u radu s djecom i mladima rizičnog ponašanja, međutim, mislim da je razvoj kreativnih sposobnosti na ovim prostorima premalo zastupljen u svim životnim područjima i na neki način kreativnost se još uvijek promatra kao privilegij talentiranih umjetnika ili inovatora te velik broj ljudi, osobito djece, uopće nije svjestan vlastitih kreativnih potencijala.

Jedna od mnogih definicija kreativnosti navedeni fenomen opisuje kao stvaralaštvo kojim se stvara nešto novo, drukčije od dotadašnjeg, što uključuje rješavanje problema na svoj način, otkrivanje dotada nepoznatog (Ozimec, 1987, prema Škrbina, 2013), odnosno kreativnost opisuje kao sposobnost povezivanja dosad nepovezanih informacija te na taj način pronalaženja novih rješenja (Škrbina, 2013).

Promatrajući navedene definicije stječe se dojam da je upravo razvoj kreativnosti važan preduvjet za razvoj osobnih potencijala i uspješno funkcioniranje na bilo kojem životnom području.

2 Jon Kabat-Zinn definira Mindfulness kao svjesnost koja se pojavljuje zbog namjernog usmjeravanja pozornosti u sadašnjem trenutku te prepuštanjem bez prosuđivanja iskustvu koje se događa u svakom trenutku (Kabat-Zinn, 1990, prema Weiner, 2012). 
Tragajući za kreativnom metodom, koja bi bila primjenjiva u socijalnopedagoškom radu s populacijom djece i mladima s problemima u ponašanju, 2015. godine otkrila sam metodu fraktalnog crteža, koju unatrag tri godine primjenjujem u osobnom razvoju i u profesionalnom radu.

Metoda me podsjetila na spontano črčkanje i šaranje po papirićima, najčešće dok vodimo duge telefonske razgovore, a koje na nas ima umirujuće djelovanje. Na sličan su način i djeca, koju sam podučavala ovoj metodi, „fraktalnim šaranjem" ulazila u jedno opuštajuće stanje i lakše se otvarala komunikaciji o različitim problematičnim područjima, o kojima inače ne bi otvoreno govorila.

Ideju primjene te metode u radu s djecom s problemima u ponašanju podržala je kao značajnu i autorica te metode, te je ista realizirana u okviru projekta koji ću, između ostaloga, predstaviti u ovom radu. Izuzev spomenutog projekta, u radu će biti prikazane i druge mogućnosti primjene ove metode $u$ individualnom radu s različitim korisnicima Centra za socijalnu skrb, kao i skupnom radu tijekom antistresnog programa sa stručnim djelatnicima iste ustanove.

Na temelju svojega dosadašnjeg, kako osobnog iskustva tako i iskustava osoba koje redovito prakticiraju tu metodu, metoda fraktalnog crteža pokazala se primjenjivom i korisnom u učinkovitijem nošenju sa stresnim i rizičnim situacijama, kao i jačanju pozitivnih osobina kod svih dobnih skupina.

\section{Metoda fraktalnog crteža}

Pojam fraktala primarno je vezan uz matematičku znanost budući da ga je matematičar Benoît Mandelbrot 1975. godine prvi put upotrijebio kada je matematičku formulu pomoću računalne grafike pretvorio u sliku, čiji je primjer prikazan na Slici 1 (Komov i Polujahtova, 2014).

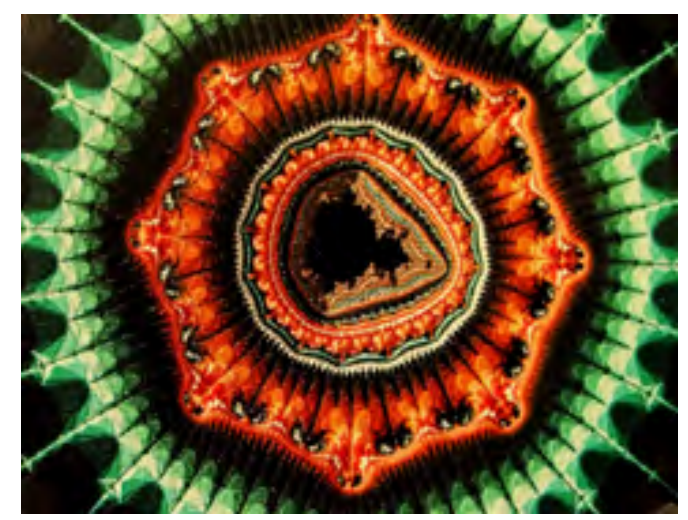

\section{Slika 1. Mandelbrotov fraktal u računalnoj grafici ${ }^{3}$}

FRAKTAL označava nepravilan oblik u kojemu ima i nekog reda, odnosno oblik koji u svakom svom dijelu odražava cjelinu (Komov i Polujahtova, 2014). Budući da u prirodi gotovo ništa nije formirano od ravnih crta, nego od nepravilnih oblika u kojima ipak postoji određen red i simetrija, fraktalnu geometriju možemo nazvati matematikom prirode i nas samih. Slijedom navedenoga, fraktalne oblike možemo naći svuda oko nas, a kao najpoznatije fraktale možemo navesti snježnu

3 izvor: Andrijić Z. (2005). Zanimljiva znanost: Fraktali. Plavi planet — magazin svjesnosti, 4, 40-43 
pahuljicu (Slika 2), list paprati (Slika 3), ali i naš živčani sustav koji također ima fraktalnu strukturu, što je prikazano na Slici 4.

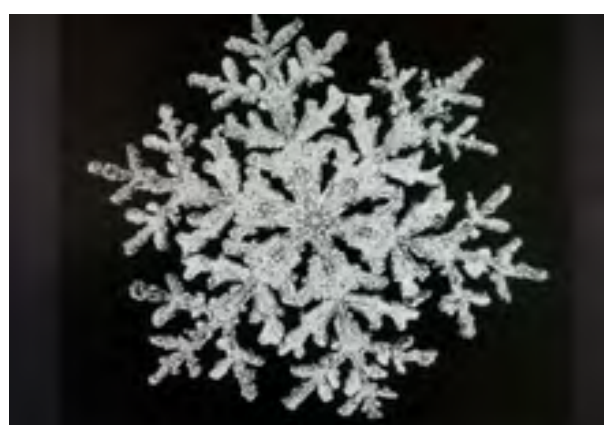

Slika 2. Snježna pahuljica ${ }^{4}$

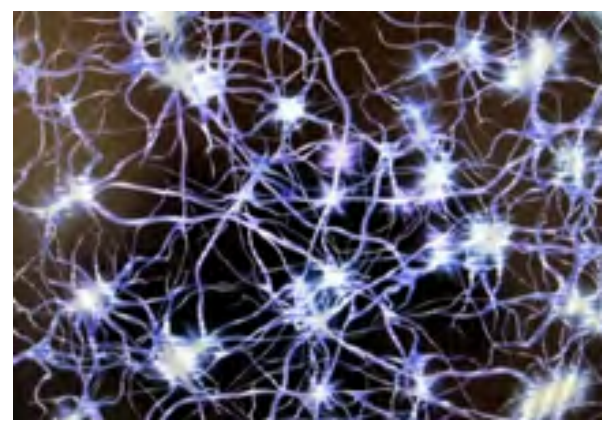

Slika 4. Fraktalna struktura neuronske mreže ${ }^{6}$



Slika 3. List paprati ${ }^{5}$

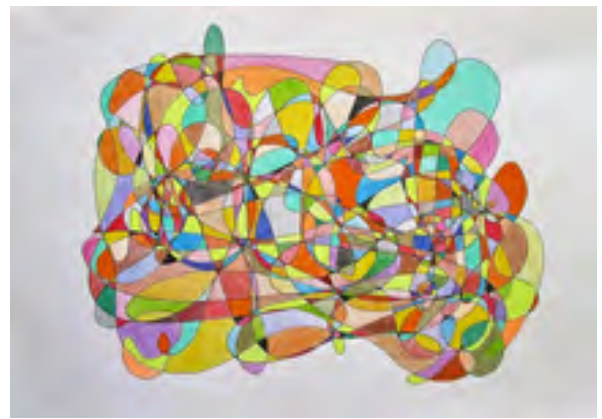

Slika 5. Fraktalni crtež

Na Slici 5 prikazan je primjer fraktalnog crteža koji se upravo tako naziva zbog svoje strukture mozaika koji se grana od većih prema sve manjim dijelovima, ali i činjenice da se u svakom njegovu djeliću zrcali cjelokupnost našeg postojanja, budući da svako polje u crtežu predstavlja određeno područje našeg života, odnosno pojedino životno razdoblje. Kao što je Mandelbrot učinio vidljivom matematičku formulu, tako i mi izradom fraktalnog crteža činimo vidljivim skrivene, apstraktne dijelove sebe poput naših misli i emocija, odnosno ostavljamo na papiru otisak svoje osobnosti. Na taj način povezujemo se i upoznajemo sa sobom i sa svijetom oko sebe, te učimo proširiti granice razvijanjem svojih potencijala, a olovka i papir postaju naši alati kojima otkrivamo mjesto na kojemu se trenutno nalazimo i, crtajući prema određenim pravilima, kreiramo naš put do željenog cilja.

Slijedeći ranije navedene principe fraktalnosti možemo predočiti i naš organizam kao jedan složeni sustav poput biokompjutora, u kojemu se nalazi jedan od najinspirativnijih fraktala, naša DNK. S obzirom da su principi fraktalnosti usko povezani s principima stvaranja, danas se u svim sferama znanosti, osobito kvantnoj fizici i medicini, proučavaju načini korištenja fraktalnih koncepata u procesima iscjeljenja uma i tijela.

\footnotetext{
4 izvor: www.crtanje-fraktala.com/o-crtanju-fraktala

5 izvor: https//wordpress.com/2017/02/20/fraktalna-geometrija-matematika-u-službi-majke-prirode

6 izvor: https://medatrio.com/parkinsons-sinapsi-neuroni

7 izvor: Hundrić V., 2017.
} 
Metodu fraktalnog crteža razvila je 1991. ruska klinička psihologinja i obiteljska terapeutkinja Tanzilija Polujahtova, koja živi i djeluje u Jekaterinburgu (Rusija). Autorica metode poznata je po istraživanjima na području rehabilitacijskih programa i bioenergoinformacijskih tehnologija. Ona je i autorica korektivnih metoda na području fizike boja, oblika i zvukova, odnosno metoda korekcije čovjekova psihofizičkog stanja poput metode fraktalnog crteža, te metode korekcije glasom. U suradnji s ruskim fizičarem Komovim napisala je knjigu „Izvornik fraktalne mudrosti ili nov pogled na naše mogućnosti". U Hrvatsku je tu metodu uvela 2011. godine Martina Kosec, profesorica likovnog odgoja, koja u okviru svoje tvrtke „Puni potencijal" provodi edukacije i radionice istom metodom te piše knjige vezane za navedenu tematiku. S obzirom na svoj dugogodišnji radni staž u osnovnoškolskom sustavu, kao i postignute pozitivne rezultate u primjeni metode u radu s učenicima i njihovim roditeljima, njezin je osobit interes usmjeren na uvođenje te metode u školski sustav.

Nastanak metode, njezina autorica Tanzilija Polujahtova, pojasnila je vlastitom potrebom za unapređenjem klasičnih psiholoških testova i namjere da se utjecaj ispitivača na ispitanika svede na najmanju moguću mjeru (Komov i Polujahtova, 2014). Nadalje, u svojim javnim izlaganjima i edukacijama, Polujahtova je pojasnila da je inspiraciju za tu metodu dobila, između ostaloga, promatrajući kretanje slijepih osoba u prostoru. Rekla je da je potvrdila činjenicu da se u slučaju kada čovjek ne koristi jedno osjetilo poput vida, aktiviraju njegovi ostali unutarnji resursi za snalaženje u prostoru i novim situacijama, odnosno jačaju i razvijaju se novi načini percepcije. Na isti je način zaključila da će čovjek, koji se zatvorenih očiju nauči kretati olovkom po papiru, aktivirati svoje unutarnje uspavane resurse i bolje se snalaziti u novim i nepoznatim životnim situacijama (Polujahtova, 2016, Edukacija: Fraktali u psihoterapiji, Zagreb).

Sama metoda bazirana je na principima art-terapije, Brain Gyma ${ }^{8}$, kromoterapije ${ }^{9}$, grafomotoričkih vježbi ${ }^{10}$, te neuroznanstvenim konceptima ${ }^{11}$. U svom konceptu polazi od činjenice o povezanosti motorike ruku i čovjekovih psihofizioloških stanja, te spoznaje da različite kombinacije linija i boja različito djeluju na nas. Također, razrađene su psihofiziološke karakteristike svake boje koja ima značenje specifično samo za ovu metodu. Važno je naglasiti da se boja ovdje promatra primarno svojom energetskom funkcijom.

Tehnologija metode vrlo je jednostavna i prirodna, a sastoji se od spontana crtanja linija i bojenja. Njezina specifičnost je u tome što isključuje svjestan utjecaj tijekom izrade crteža, na način da se crteži većim dijelom izrađuju zatvorenih očiju, što pokreće naše unutarnje resurse i dovodi nas do jednog ugodna, umirujućeg stanja.

8 Brain Gym, u prijevodu Gimnastika za mozak, razvio je u drugoj polovici prošlog stoljeća edukator i znanstvenik Paul E. Dennison. Radi se o senzomotoričkom programu Edukacijske kineziologije koji uključuje 26 aktivnosti različitih pokreta kojima potičemo senzomotorički razvoj, senzoričku i senzomotoričku integraciju, što rezultira djelotvornijim učenjem. Vježbama se potiče integracija sustava uma i tijela, odnosno integrirano djelovanje obiju moždanih polutaka i tijela u okviru triju dimenzija — lateralnosti, centriranja i fokusiranja (Dennison P. E, Dennison G. E., 2007).

9 Kromoterapija, u prijevodu terapija svjetlošću i bojom, primjenjivana je još u starim civilizacijama poput Egipta, odnosno Grčke i Rima, a zasnovana je na spoznajama o blagotvornom i iscjeljivajućem utjecaju sunčeve svjetlosti i njegovu spektru boja na čovjekovo psihofizičko zdravlje. Pionir moderne terapije bojama, fizičar Niels R. Finsen, 1903. dobio je nagradu za liječenje tuberkuloze kože pomoću svjetlosti i UV zračenja, a optometrist dr. J. I. Liberman, više od četiri desetljeća bavi se proučavanjem utjecaja svjetlosti i boja na ljudsko zdravlje, te primjenom tzv. fotodinamičke terapije ostvaruje uspješne rezultate u liječenju najtežih bolesti (Muck, Kosec, 2019).

10 Grafomotoričke vježbe pomažu razvijanju različitih vještina poput fine motorike šake, vizualne percepcije, okulomotorne koordinacije, te glasovne analize i sinteze, koje omogućavaju osobi držanje olovke dok piše, odnosno ovladavanje vještinom pisanja (Šprljan Szivo T., 2017., Što je grafomotorika, kako se razvija i kako ju poboljšati, preuzeto s https://www.maminsvijet.hr/briga-o-djeci/vrtic-i-jaslice/ grafomotorika-sto-je-kako-se-razvija-i-kako-ju-poboljsati).

11 Neuroznanost proučava stanične, funkcionalne, bihevioralne, evolucijske, računalne, molekularne, stanične i medicinske aspekte živčanog sustava (Orlović, I., 2019., Što je neuroznanost, preuzeto s https//hr.onlinemedicineinfo.com/what-is-neuroscience-79386). 
Prvi crtež izrađuje se, kao što je spomenuto, zatvorenih očiju, povlačenjem neprekinute linije crnom kemijskom olovkom na horizontalno položenom bijelom papiru A4 formata tijekom 60 sekundi i zove se testnim crtežom. Isti nam služi za upoznavanje s takvim načinom crtanja i navedeni crtež ne bojimo. Idući crtež radi se prema istom principu i zove se dijagnostičkim fraktalnim crtežom te se nakon dovršenja mreže, koja se sastoji od različitih polja dobivenih presijecanjem linije, pristupa bojenju crteža isključivo drvenim bojicama prema određenim pravilima. Iz tog crteža može se utvrditi čovjekovo trenutno psihofizičko stanje te naznake i drugih, kasnije nabrojenih karakteristika. Ako čovjek u zadanom vremenskom roku izradi tri takva crteža, putem analize ponavljajućih karakteristika i elemenata crteža (linije koja daje informacije o tijeku naših misli i ponašanju, te boje koja oslikava naše emocionalno stanje), razrađenih putem tzv. ključa sa 75 parametara, mogu se iščitati informacije o čovjekovim emocionalnim stanjima, talentima i skrivenim snagama, karakternim osobinama, ali i ograničenjima koji mu otežavaju funkcioniranje, što ovu metodu čini značajnim dijagnostičkim sredstvom. Ovdje vrijedi napomenuti da je za pouzdanu holističku dijagnostiku putem fraktalnog crteža, osim znanja i snažne intuicije, potrebno i veliko iskustvo. Osim toga, ova metoda razvija i našu percepciju, te smo uz više izrađenih i analiziranih crteža, odnosno dubljim ulaskom u metodu, sposobni zapažati više detalja.

Analizu fraktalne linije Polujahtova je među ostalim utemeljila i na polazištima koja potječu iz grafologije, odnosno teze da se iz nacrtane linije, koju osoba horizontalno povlači zatvorenih očiju, može razabrati psihofizičko stanje. U jednom od istraživanja 1990. ona je analizirala 60 crteža osoba koje su zamoljene zatvorenim očima na papiru iscrtati liniju u obliku zapisa signala s amplitudom i frekvencijom prema vlastitom osjećaju. Dobiveni je zapis za Polujahtovu bio usporediv s elektrokardiogramskim (EKG) signalom, kojim se u medicini utvrđuje pravilnost rada srca. U svojoj analizi ona je uspoređivala frekvenciju, periodičnost, visinu vrhova i intervale iscrtanih signala te zapazila primjetne elemente koji iskaču iz signala na pojedinim dijelovima krivulje. Dobiveni rezultati omogućili su joj podjelu ispitanika na tri skupine. U prvoj su skupini bile osobe koje su iscrtale idealan oblik signala, poput onoga izišla ispod tiskarskog stroja; u drugoj je bilo 5-7 \% odstupanja od prosječnoga iscrtanog signala, a u trećoj skupini odstupanja su se kretala od 7 \% do $12 \%$. Daljnjim istraživanjima otkrila je da su kod osoba iz posljednje skupine postojale određene zdravstvene tegobe poput ometenog protoka kisika u mozgu. Autorica je ubrzo nakon toga prešla na dvodimenzionalno crtanje linije po cijeloj površini papira te je na taj način nastala fraktalna linija, odnosno fraktalno crtanje (Muck i Kosec, 2019).

Nakon dijagnostičkih, izrađuju se korekcijski fraktalni crteži gdje osoba samo crtanjem linija i bojom prema određenim pravilima, odnosno korištenjem novih vrsta linija i elemenata fraktalnog crteža, kao i terapeutskim kombinacijama boja (ovdje je uz drvene boje dopuštena i primjena tankih flomastera) može samostalno učiniti korekciju i harmonizaciju vlastitoga unutarnjeg stanja te raditi na unošenju sklada u sva životna područja, što je ujedno i cilj te metode. Pri tome se primjenjuje princip fraktalnosti prenošenja postignutoga sklada na crtežu na sva područja našeg života.

Postoje korekcijski crteži namijenjeni korekciji trenutnog stanja na način da se u crtež unose drukčije linije od onih na inicijalnom, odnosno dijagnostičkom crtežu, prema jednostavnijim pravilima. Takvu vrstu crteža primjenjivala sam i u projektu koji ću kasnije predstaviti. Za početak osoba može izraditi mali ciklus od ukupno sedam crteža u nizu, čime će postići određene promjene poput boljeg raspoloženja, koncentracije, jačanje motivacije za rad, otvaranje kreativnih potencijala, no, 
ponekad u nekih osoba može doći i do izviranja potisnutih emocionalnih sadržaja, što nije uvijek ugodno. Ako je osoba spremna na veće promjene, može se upustiti u cjelovit proces korekcije izradom velikog ciklusa od ukupno 21 crteža. Izuzev složenijih pravila i većih crtačkih izazova uvođenjem zahtjevnijih elemenata i simbola (primjerice petlja, meandra, valova, spirala te stiliziranih simbola brojeva i slova), velikim ciklusom čovjek dublje uranja u vlastitu podsvijest i moglo bi se reći da prolazi jednu vrstu osobne psihoterapije suočavajući se s vlastitim ograničavajućim obrascima koje, primjenjujući ovu metodu, nastoji transformirati. Izuzev navedenih, postoje još i umjetnički fraktalni crteži, fraktalni crteži podrške, fraktalne mandale i mnogi drugi, a metoda se i dalje intenzivno razvija i nadopunjuje novim saznanjima.

Fraktalni crteži izrađeni prema pravilima korekcije, prema navodima autorice, mogu imati povoljan učinak i samim izlaganjem u prostoru, te ista navodi primjere bolnica u Rusiji u kojima je uočen brži oporavak pacijenata s odjela na kojima su bili izloženi fraktalni crteži. Osim toga, autorica je temeljem više od 25 godina iskustva i kliničkih istraživanja zaključila da primjena metode ima opuštajući, umirujući učinak na crtača, pridonosi smanjenju stresa i napetosti, može djelovati na razvoj i jačanje kognitivnih funkcija, odnosno pažnje, koncentracije, motivacije za rad, ustrajnosti, strpljenja, discipline, kreativnosti, samopouzdanja, fine motorike, tolerancije te olakšati stanja poput traume ili bolesti (Komov i Polujahtova, 2014).

Među još nekim prednostima ove metode mogla bih istaknuti prije svega dostupnost širokoj populaciji, odnosno svim ljudima neovisno o dobi, spolu, obrazovanju ili crtačkom umijeću te jednostavnosti primjene i ekonomičnosti budući da ne iziskuje velike materijalne izdatke (za izradu crteža potrebna je crna kemijska olovka, set drvenih bojica koji treba sadržavati 13 osnovnih boja i papir A4 formata nešto grublje teksture). Jako je važno da čovjek u izradi crteža koristi papir nešto grublje teksture, kvalitetnu kemijsku olovku i set drvenih bojica.

\section{Projekt „linije i boje otkrivaju mene - crtanjem fraktala do razvoja potencijala djece i mladih"}

Kao što je ranije već spomenuto, izradu Projekta podržala je sama autorica metode Tanzilija Polujahtova, prepoznavši važnost njezine primjene u radu s djecom i mladima s problemima u ponašanju u odnosu na moguće dobrobiti te $s$ obzirom da ista do sada nije primjenjivana u navedenoj populaciji.

Projekt je, dakle, primarno bio namijenjen djeci i mladima s problemima u ponašanju koji se nalaze u institucijskom tretmanu, ali i stručnjacima koji rade s njima, budući da je upravo navedena populacija procijenjena osobito ranjivom i u potrebi za potporom. Realizaciju projekta pod pokroviteljstvom Ministarstva zdravstva omogućila je Udruga za kreativni socijalni rad iz Zagreba na čelu sa socijalnom radnicom Danijelom Đurak, a isti se provodio u razdoblju od siječnja do listopada 2017. u prostorijama Udruge, Centru za pružanje usluga u zajednici Zagreb — Dugave i Župančićeva, Odgojnom zavodu Turopolje i Odgojnom domu Bedekovčina.

Ciljevi Projekta:

— upoznavanje polaznika s osnovama metode fraktalnog crteža i mogućim dobrobitima primjene iste 
— osposobljavanje za samostalnu primjenu metode prilagođene specifičnim karakteristikama i potrebama ciljane populacije, uz osobno terapeutsko iskustvo same metode

— jačanje kapaciteta stručnjaka koji rade s navedenom dječjom populacijom

— preveniranje sindroma sagorijevanja na radnome mjestu

— preveniranje rizičnih dječjih aktivnosti

— razvoj potencijala djece s teškoćama u ponašanju, osobito u odnosu na jačanje kapaciteta za učinkovitije nošenje sa stresnim i problematičnim situacijama.

Program Projekta osmišljen je u suradnji s prof. Martinom Kosec, u ciklusima od triju povezanih radionica, prema pojednostavnjenom programu, na kojima su osobe educirane iz osnova primjene metode fraktalnog crteža putem predavanja i praktičnog rada, odnosno osobnog iskustva metode izradom dijagnostičkoga, korekcijskoga i fraktalnog crteža podrške. Radionice su prilagođene s obzirom na specifičnosti strukture pojedinih skupina polaznika, odnosno, kao što je ranije spomenuto, radila se korekcija trenutnog stanja putem linije i boje te su na kraju dane upute i sugestije za daljnji samostalan rad. Polaznici radionica stekli su na taj način dovoljno znanja i iskustva za samostalno korištenje metode.

Program radionica za stručnjake razlikovao se od programa namijenjenoga djeci po nešto složenijim pravilima izrade samih crteža, poput uvođenja osnovnih elemenata u korekcijskim crtežima, te primjeni zahtjevnijeg načina bojenja. Kod djece je primijenjen popustljiv program, na način da im je dopušteno više slobode u izradi crteža, da bi ostala motivirana za dovršenje započetih radova, odnosno od njih se tražilo poštivanje osnovnih pravila metode te se korekcija radila isključivo putem unošenja drukčijih vrsta linija od prisutnih na dijagnostičkom crtežu uz pojednostavnjenu shemu korištenja boje. Ako neko dijete nije moglo u potpunosti slijediti ni osnovna pravila, dopušteno mu je raditi kako najbolje može, s obzirom da kod ovakvih crteža i najmanji uložen trud i angažman u skladu s mogućnostima djeteta ima povoljan učinak. Ako je neko dijete iskazalo interes, moglo je isprobati i korekciju s elementima, što se ispostavilo previše zahtjevnim, tako da najčešće takav rad nisu dovršavali. Treća radionica i za djecu i za stručnjake bila je identična. Podučavani su jednoj formi umjetničkoga fraktalnog crteža, odnosno fraktalnom crtežu podrške koji se izrađuje u situacijama kada imamo potrebu za podrškom, primjerice u teškoj životnoj situaciji ili u realizaciji nekog cilja, što sam smatrala iznimno korisnim upravo za djecu u institucijskom tretmanu. U praktičnom dijelu izrađivao se fraktalni crtež podrške na dvjema zadanim temama: anđeo ili drvo, pri čemu je svaki sudionik mogao sam izabrati temu, odnosno motiv koji je želio izraditi.

Nakon svake radionice polaznici su popunjavali evaluacijske upitnike za samoprocjenu stanja prije radionice i nakon nje te davali mišljenje o samoj metodi i načinu njezine prezentacije. $U$ upitnicima za djecu većina pitanja bila je zatvorenog tipa, dok su pitanja za stručnjake bila otvorenoga, zatvorenoga i kombiniranog tipa.

Djeci su postavljana pitanja o tome kako su se osjećala prije radionice, tijekom nje i nakon same radionice, kako su im se svidjele radionice i način njihova vođenja, kakav je osjećaj u njima izazvalo crtanje i bojenje fraktalnog crteža, hoće li nastaviti s crtanjem fraktalnih crteža nakon radionica, te vide li korist od primjene te metode u svom životu. 
Stručnjaci su odgovarali na ista pitanja kao i djeca uz proširenu ponudu mogućih odgovora, te dodatna pitanja o tome kakva su iskustva imali tijekom dosadašnjeg crtanja, mogu li povezati svoj pristup životu s načinom pristupanja izradi crteža (prepoznaju li neke svoje obrasce funkcioniranja), smatraju li da tehniku mogu koristiti u osobnom razvoju i u radu s drugima, te kako bi ocijenili korisnost radionica uz davanje prijedloga i sugestija za iduće radionice.

Analiza evaluacijskih upitnika izrađena je utvrđivanjem prosječnih frekvencija javljanja pojedinih odgovora tijekom svih triju radionica u odnosu na pitanja koja su se ponavljala u svim trima upitnicima, te frekvencija javljanja odgovora na pitanja vezana isključivo za jednu radionicu (jedan upitnik), uz isticanje zapaženih odstupanja i specifičnosti u odnosu na pojedine radionice, te skupine sudionika.

Važno je napomenuti da su radionice s djecom bile organizirane na dobrovoljnoj osnovi, odnosno sudjelovala su isključivo djeca koja su pokazala interes za radionice i svako je dijete u bilo kojem trenutku moglo odustati. Isti je princip bio zastupljen i pri popunjavanju evaluacijskih upitnika tako da je najčešće bilo manjih odstupanja u broju sudionika koji su popunili upitnike u odnosu na ukupan broj sudionika na radionicama.

Vezano za zaštitu identiteta i objavljivanje dječjih fotografija, želim napomenuti da je s voditeljima i stručnim djelatnicima ustanova dogovoreno da fotografije budu izrađene na takav način da ne otkrivaju identitet djece (nisu potpuno vidljiva njihova lica ni oči), odnosno da fokus bude na ozračju samih radionica i njihovu aktivnu sudjelovanju u njima, te njihovim radovima. Djeca su na fotografijama prikazana u pozitivnu kontekstu, budući da su uključena u konstruktivnu i poželjnu aktivnost, tako da su sami odgojitelji i djeca, koja su također pristala na takav način predstavljanja njihova rada, zatražili fotografije radi uređenja panoa u skupini i internih izložaba. Navedeno ukazuje na činjenicu da su djeca bila ponosna što svojim članovima obitelji tijekom posjeta mogu prikazati svoj rad i angažman tijekom boravka u ustanovi. Mislim da na ovakav način prezentirane fotografije djecu nisu izložile bilo kakvu obliku nelagode ili poniženja, odnosno da prikaz u navedenom kontekstu može samo poticajno djelovati na drugu djecu, kao i slične ustanove, motivacijom na uvođenje različitih kreativnih aktivnosti, te da bi se djecu s problemima ponašanja stavilo u drukčiju, pozitivniju perspektivu s naglaskom na njihov potencijal. Isto tako, rečeno je da su fotografije namijenjene prezentaciji isključivo u stručnim krugovima radi prikaza mogućnosti primjene te metode i njezinih rezultata, te je iste prije izrade prezentacije pregledala i odobrila koordinatorica Projekta i stručnjaci u ustanovama. Identitet djece zaštićen je i prikazima slučajeva, na način da nisu objavljena njihova imena ni prezimena, kao ni drugi osobni podatci koji bi mogli otkriti njihov identitet.

U nastavku slijede prikazi radionica prema redoslijedu njihova održavanja:

\section{Radionice za stručnjake koji rade s djecom i mladima s problemima u ponašanju}

U Udruzi za kreativni socijalni rad održana su dva ciklusa radionica u razdoblju od 20. siječnja do 18. veljače 2017., u kojima je sudjelovalo 16 stručnjaka, socijalnih radnika i socijalnih pedagoga, koji rade izravno s djecom i mladima u institucijskom tretmanu.

Svaka radionica trajala je četiri sata, a iste su u praktičnom dijelu bile prilagođene različitoj strukturi pojedine skupine na način da su polaznici mogli birati jednostavniji ili složeniji praktični 
zadatak, osobito u korekcijskim crtežima. Naime, korekcija je u programu za stručnjake, kao što je već spomenuto, bila planirana složenijim načinom s uvođenjem elemenata koji su iziskivali više vremena i truda, međutim, budući da su kod pojedinih polaznika zamijećene teškoće izrade crteža na takav način, a praktičan rad trebao je imati primarno opuštajući učinak na polaznike, dopušteno je da sami izaberu način korekcije. Zanimljiva je činjenica da su u I. ciklusu radionica svi sudionici kod izrade fraktalnog crteža podrške birali motiv anđela, dok su polaznici II. ciklusa birali isključivo motiv drveta. Radovi pojedinih polaznika i ozračja s radionice prezentirani su na slikama 6, 7, 8 i 9.

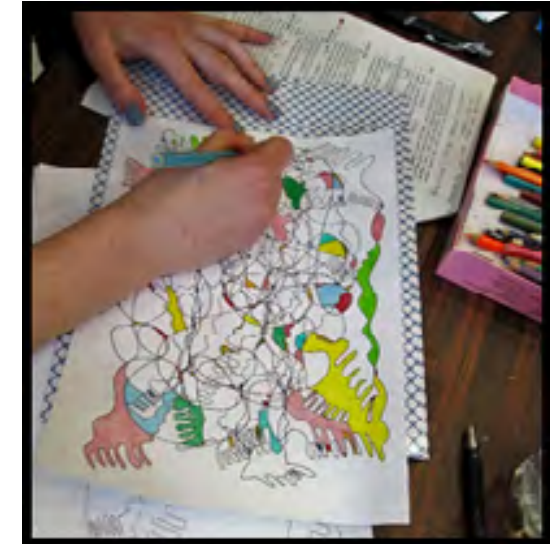

Slika 6. Proces izrade korekcijskog crteža, element - valovi

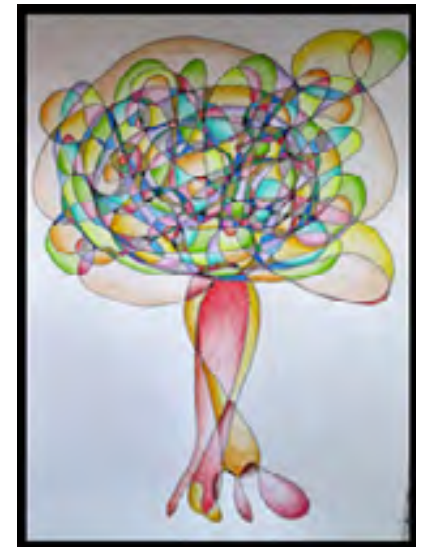

Slika 7. Fraktalni crtež podrške

Samim sudjelovanjem u ovim radionicama stručnjaci su pokazali motivaciju za stjecanjem novih znanja i vještina. Na temelju analize evaluacijskih upitnika svih triju radionica, koje je ispunilo 16 sudionika, zaključeno je sljedeće:

Većina je stručnjaka iznimno pozitivno reagirala na temu, sam koncept i vođenje radionica (u prosjeku je 16 osoba po radionici odgovorilo da im se svidio način vođenja radionice, sama metoda i praktičan rad, dok je prosječno jedna osoba iskazala da nema ni pozitivan ni negativan stav o samoj radionici, ni o njezinu vođenju).

Tijekom radionica prosječno se 15,66 sudionika izjasnilo da im je bilo ugodno i zanimljivo, dok se 0,33 osjećalo neutralno. Stručnjaci su uvidjeli i dobrobit primjene metode ponajprije njezinim opuštajućim i umirujućim efektom (prije radionice u prosjeku se 10 osoba osjećalo dobro, tri osobe neutralno, jedna osoba umorno i pospano, dvije osobe loše, a nakon radionice prosječno se 15 osoba izjasnilo da se osjećalo ugodno i opušteno, dok se samo jedna osoba osjećala umorno).

Izrada fraktalnog crteža u prosjeku je za 12,66 osoba djelovala ugodno i opušteno; jedna se osjećala neutralno, 0,33 sudionika živciralo je izvlačenje pojedinih boja, jednoj osobi bilo je teško slijediti pravila u korekcijskom crtežu, a njih 0,66 se od početne nesigurnosti počelo osjećati sve ugodnije i opuštenije. Usporedbom svih triju radionica; na trećoj je, koja je bila najmanje zahtjevna što se tiče teorije i praktičnog rada, ustvrđeno da se najveći broj sudionika osjećao ugodno i opušteno tijekom izrade crteža (ukupno 15 osoba), u odnosu na najzahtjevniju drugu radionicu u kojoj se znatno manje osoba tako osjećalo (ukupno devetero). 
Na pitanje, mogu li povezati njihov pristup životu s načinom pristupanja izradi crteža (prepoznaju li neke svoje obrasce funkcioniranja), četiri su osobe odgovorile da nisu sigurne, a 12 osoba odgovorilo je potvrdno uz izjave poput: „volim svijetle boje, optimizam" ili „organiziranost i potreba za ravnotežom".

O svojim se iskustvima crtanja tijekom svih triju radionica 13 sudionika izjasnilo da je imalo pozitivna iskustva ("osjećala sam se opušteno i puna samopouzdanja”, "opuštanje u radu s bojama i sve dublje razumijevanje procesa", "slobodnija ruka, lakše kombiniranje boja", osjećala sam se čarobno") dok se ostali nisu izjasnili.

Ukupno 15 sudionika izjasnilo se da vide mogućnost primjene ove metode u osobnom razvoju i profesionalnom radu, osobito s djecom, a 14 osoba ocijenilo je ove radionice korisnima. U prijedlozima i sugestijama šest je osoba izjavilo da bi željele više ovakvih radionica, odnosno njihov nastavak, te je bilo prijedloga da se izbjegnu digresije zbog čestih upadica s pitanjima sudionika, kao i uvođenje više pojašnjavanja tijekom samoga procesa crtanja. Ovdje bih željela napomenuti da se radi o skraćenom programu s osnovama metode, kao i kraćem vremenskom okviru od uobičajenog za cjelovite edukacije, koje su znatno zahtjevnije i dugotrajnije zbog čega je vremenski nemoguće odgovoriti na sva pitanja i zahtjeve sudionika. Zbog ranije navedenoga, zainteresiranim je sudionicima ponuđena mogućnost vođenja u daljnjem procesu, čemu su se pojedinci odazvali i nastavili s edukacijom.

Također, važno je istaknuti i činjenicu o kojoj su se stručnjaci izjasnili tijekom razgovora s voditeljicom radionica; naime, izjavili su da im je značajno bilo i samo druženje tijekom procesa crtanja i osobno osnaživanje međusobnom podrškom i komunikacijom u ugodnoj i opuštenoj atmosferi (poput neke vrste supervizije), ali i dobivanje konkretnog alata koji mogu primjenjivati u različitim situacijama.

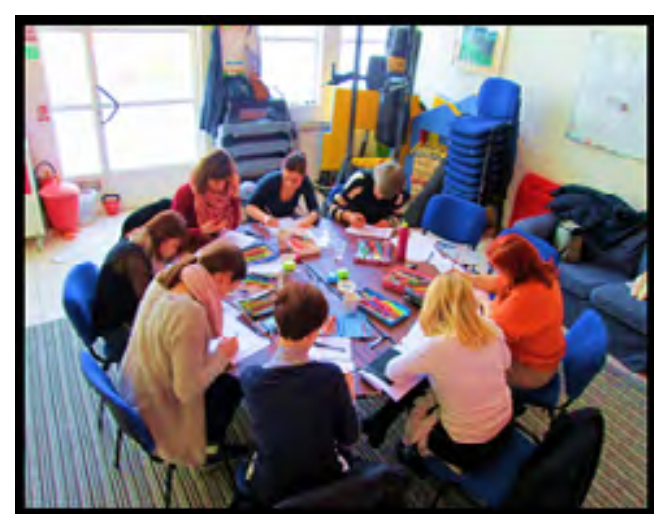

Slika 8. Atmosfera s radionice



Slika 9. Dijagnostički fraktalni crtež

Komentari nekih od polaznika radionica iskazani u evaluacijskim upitnicima:

— „Korisna tehnika za prvu pomoć. Primjenjivo u svim fazama rada s korisnicima, najviše primjenjiva u osobnom rastu i razvoju."

— "Imala sam tijekom crtanja ugodna iskustva s raznim spoznajama i doživjela emocionalno oslobođenje." 
— "Počela sam se baviti potisnutim problemima i postala svjesnija sebe i svega oko sebe".

— "Osobno bih voljela da je više ovakvih radionica."

— "Tehnika se čini pristupačna i jednostavna."

— "Opuštala sam se i uživala."

— "Poučno i ugodno."

— "Mogu potpuno povezati moj pristup životu i način razmišljanja sa pristupanjem izradi fraktalnih crteža."

Povratnim informacijama pojedinih polaznika utvrđeno je da su metodu nastavili primjenjivati u osobnom radu s djecom te verbalizirali pozitivna iskustva. Primjerice, neki od sudionika koristili su se metodom za opuštanje i relaksaciju nakon radnog vremena te zamijetili veću smirenost i jačanje motivacije za rad. Primjenjivali su je i u radu s djecom koja su pokazala interes te su zamijetili da su djeca, koja su crtala i motivirala drugu djecu koja na početku nisu pokazivala interes, kasnije počela aktivnije sudjelovati u svim aktivnostima i općenito bila boljeg raspoloženja.

\section{Radionice za djecu održane u Centru za pružanje usluga u zajednici Zagreb — intenzivni domski tretman za odgoj muške djece i mladeži — Župančićeva}

Održan je jedan ciklus radionica u trajanju od dva sata u razdoblju od 4. travnja do 26. travnja 2017. u kojemu je sudjelovalo osmero djece u dobi od 11 do 14 godina. Djeca su, izuzev PUP-a, manifestirala čitav niz smetnji od poteškoća učenja, ADHD-a i ADD-a, različitih psihičkih, osobito emocionalnih smetnji i psihijatrijskih dijagnoza. Uglavnom potječu iz obitelji niskog socioekonomskog statusa i socijalno depriviranih sredina. Nekoliko djece bilo je izrazito traumatizirano zbog zanemarivanja ili zlostavljanja u obitelji.

Izazov tih radionica bio je u traženju načina kako motivirati grupu dječaka za crtanje na način da je unaprijed pripremljeno nekoliko koncepata, primjenjivanih kasnije i u drugim radionicama s djecom, koji su prilagođavani na licu mjesta u skladu s trenutnim stanjem i raspoloženjem članova skupine. Najprije im je zadatak prezentiran poput izazova, na način da izrada fraktalnih crteža nije jednostavna, te da iste mnogi započnu, ali samo oni najuporniji dovršavaju, što je odlika koju vežemo uz uspješne ljude. Tada su djeca crtanje doživjela kao priliku dokazati sebi i drugima vlastitu upornost i odvažnost, te se trudili dovršiti radove koliko god je nekima od njih to bilo teško. $\mathrm{Na}$ taj način osnaživali su svoju volju, upornost, dosljednost, disciplinu te na kraju bili ponosni dovršenjem zadatka. Dječaci su na taj način osjećali da mogu biti uspješni u nekoj aktivnosti i imali su prilike vidjeti konkretne rezultate svojeg rada, što je za njih bilo svakako motivirajuće. Osim toga, djecu je na dovršenje crteža motivirala i mogućnost izlaganja njihovih radova na izložbi nakon završetka projekta, što ih je osobito veselilo. U motivaciji su pomogle i usporedbe sa sportom, što im je bilo osobito blisko, na način da crtanjem treniraju svoj mozak kao što sportaši treniraju mišiće, te da fraktalno crtanje povlačenjem linije s jedne na drugu stranu papira ima poveznicu sa Brain Gymom i vježbama koje sportaši koriste u svojim treninzima, a neke od navedenih vježba su tom prilikom i naučili. 
Specifičnost radionica u ovoj ustanovi bili su izazovni trenutci u situacijama uoči odlaska na vikend, kada većina djece na početku nije bila raspoložena za crtanje, međutim, kasnije ih je privukla pozitivna atmosfera koju bi stvorila dva-tri dječaka koji su sudjelovali u radionici i spontano in se sve više uključivalo u proces, tako da je na kraju crtala čitava skupina. Dio atmosfere s jedne od radionica prikazan je na Slici 12.

Djeca koja nisu bila motivirana za crtanje i bojenje velikog broja malih polja, budući da je isto zahtijevalo više truda (no, ima i svoj dijagnostički značaj), pokazala su interes za bojenje pokaznih predložaka crtanih debelim flomasterima - prikazano na Slici 10. Djecu se na rad motiviralo i na način da im se dopuštalo raditi kako najbolje mogu i kako se najugodnije osjećaju, što je za pojedince predstavljalo veliki pomak.

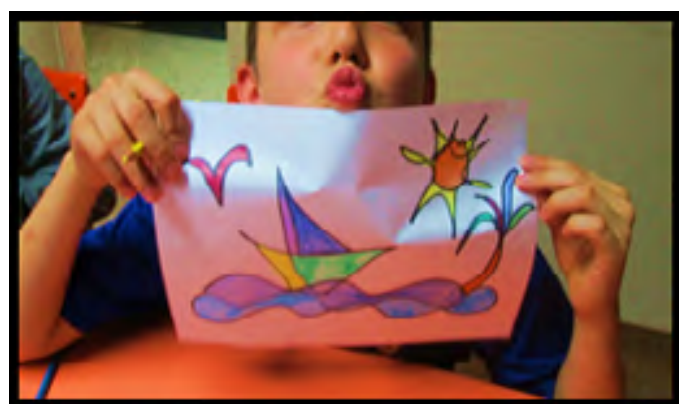

Slika 10. Fraktalni predlošci



Slika 11. Fraktalni grafit

Odgojitelji su kasnije dječacima na njihovo traženje izradili predloške poput grafita s fraktalnom teksturom koje su oni potom bojili, a na kraju počeli i samostalno izrađivati crteže, uključujući i dječaka koji nije htio sudjelovati u cijelom procesu tijekom trajanja radionica, već je isključivo bojio gotove predloške (Slika 11).

Zapazila sam i da su djeca, nakon dobivenih skripti s osnovama metode na sljedećoj radionici, pokazala zavidno znanje o značenju i djelovanju pojedinih boja, koje su odmah primjenjivali na idućim crtežima vezanima uz pojedinu situaciju. Primjerice, stavljali su na crtež više boje koja je specifična za jačanje funkcije pamćenja i učenja, premda inače pokazuju velik otpor prema učenju. Navedeno ukazuje da djeca žele biti uspješna i na području školovanja i da ih je moguće motivirati na učenje ako im se sadržaj približi na način kojim ga doživljavaju korisnim i primjenjivim u svojem životu. Odgojiteljicu skupine osobito je iznenadilo što su djeca, koja imaju dijagnosticiran ADD ili ADHD sindrom, više od puna dva sata ustrajala u crtanju bez stanke i bila potpuno fokusirana na rad. Djecu je osobito veselilo dobivanje bojica i materijala za crtanje na kraju projekta da bi mogli nastaviti samostalno izrađivati crteže. Zamijećeno je da su ih jako privlačile fluorescentne drvene bojice i svjetlucavi flomasteri raznih boja te su iste obilato koristili u korekcijskim crtežima. Zanimljivo je bilo vidjeti koliko su se vezali uz svoje crteže, željeli su ih zadržati i pokazati svojim roditeljima.

Analizom evaluacijskih upitnika (u prosjeku sedam popunjenih upitnika tijekom svih triju radionica) dobiveni su sljedeći rezultati: 
Prosječno je šestero ispitane djece reklo da se dobro osjećalo prije radionice, naspram jednom sudioniku koji se osjećao loše. Tijekom radionice svim je ispitanicima bilo zanimljivo, a nakon iste svi su odgovorili da se osjećaju ugodno i opušteno.

Broj djece koja su imala pozitivna očekivanja od radionica, bio je jednak broju djece koja nisu imala nikakva očekivanja.

Na pitanje, kako su se osjećali tijekom izrade fraktalnog crteža, u prosjeku se većina anketirane djece osjećala ugodno i opušteno (ukupno 5), 0,5 je osjećalo nelagodu, 0,5 je bilo neutralno - ni dobro ni loše, a jedno je dijete iskazalo da mu je bilo zanimljivo. Kao i na prethodnoj radionici s odgojiteljima, i ovdje je II. radionica s više pravila i zahtjevnijim crtežom, pojedincima bila najmanje ugodna.

Sva djeca odgovorila su da im se svidjela radionica i način njezina vođenja, a prosječno je šestero djece potvrdno odgovorilo na pitanje hoće li nastaviti crtati fraktalne crteže: (jedan dječak čak je napisao "zauvijek"), 0,3 je izjavilo da neće crtati, a 0,7 da nije sigurno. Moguću korist te metode u svojem životu vidjelo je petero djece, dok ostali (dvoje) nisu bili sigurni.

Radionice su provedene u skupini koju je vodila odgojiteljica koja je i sama prethodno završila edukaciju za stručnjake te je nakon toga nastavila primjenjivati metodu u radu s djecom. S obzirom da je odgojiteljica i sama prakticirala metodu, motivirala in je dodatno pokazivanjem vlastitih radova, što potvrđuje činjenicu da je dosta djece imalo određena pozitivna očekivanja od tih radionica ("da bude super", "da bude lijepo"), a da su ista ostvarena, pokazuje njihovo aktivno sudjelovanje i pozitivni komentari.

Komentari djece iskazani u evaluacijskim upitnicima nakon održanih radionica:

"Mislio sam da će me ova radionica promijeniti i zaista je. Zauvijek ću nastaviti crtati fraktalne crteže."

„Shvatio sam da su sve oko nas fraktali - naše riječi i rečenice su fraktalne, jednadžbe... cijeli svijet je fraktalan."

— "Svidjele su mi se bojice i florescentni flomasteri."

— "Na radionici crtanja mi se svidjelo što mi je crtanje fraktalnih crteža davalo energije."

— "Meni se sve svidjelo, bilo mi je super i želim da bude lijepo i da nam dođe oped."

— „Mislio sam da će biti teško, a bilo je baš lagano i zabavno." 


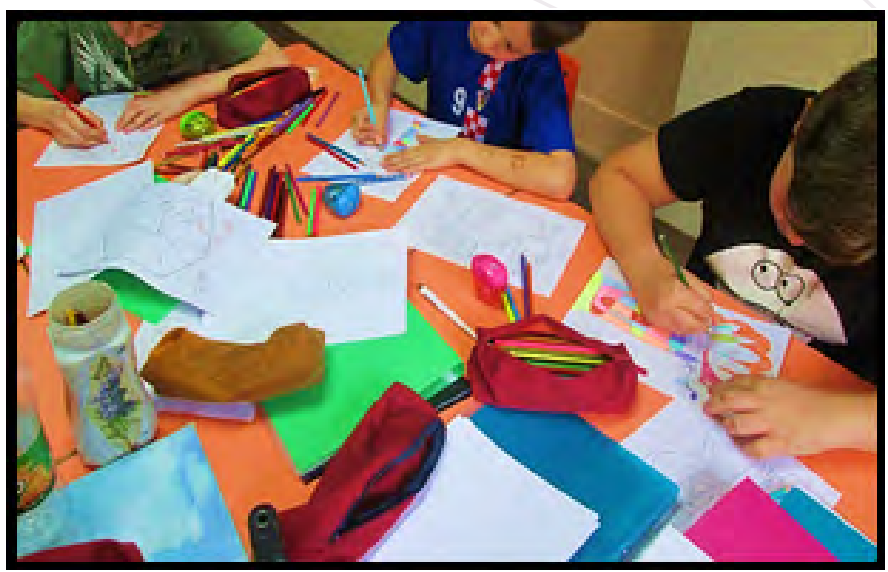

Slika 12. Atmosfera s radionice

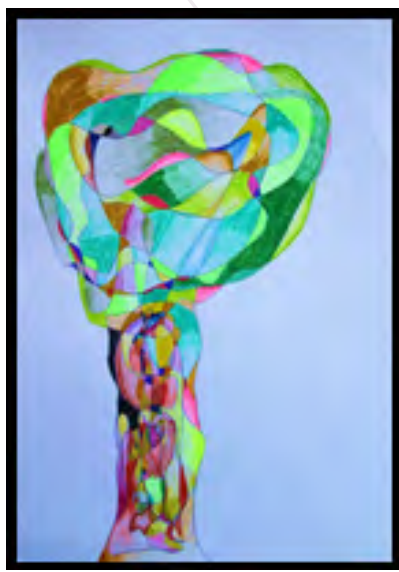

Slika 13. Fraktal podrške

\section{Radionice održane u Centru za pružanje usluga u zajednici Zagreb — Dugave}

Održana su tri ciklusa, odnosno ukupno devet radionica u trajanju od dva sata u razdoblju od 2. svibnja do 4. srpnja 2017., u kojima je sudjelovao 31 polaznik u dobi od 11 do 18 godina, odnosno djeca i mladi koji su se nalazili na stacionarnoj opservaciji tijekom mjesec dana. Na pojedinim radionicama sudjelovale su i dvije odgojiteljice, te četiri studentice na praksi. Djeca su manifestirala slične poteškoće već opisane kod djece u prethodnoj ustanovi, a stariji korisnici imali su probleme i s konzumacijom psihoaktivnih tvari, te počinjenjem kaznenih djela i prekršaja.

Specifičnost i izazov ovih radionica, u odnosu na ostale ustanove, bila je potreba prilagodbe radionica s obzirom na stalnu fluktuaciju djece te velik broj zainteresiranih za radionice, tako da su u odnosu na predviđeno sudjelovanje od maksimalno pet sudionika po radionici, znale sudjelovati čitave skupine od osmero do desetero djece. Ipak, najznačajniji otežavajući čimbenik bio je ulazak novih članova u skupinu koja je na prethodnoj radionici svladala osnove, tako da je tijekom jedne radionice bilo potrebno paralelno voditi tri različite grupe. U takvim situacijama, kao pomagači u edukaciji novih članova, angažirana su djeca koja su na prethodnoj radionici upoznata s osnovnim pravilima i koja su sa zadovoljstvom odigrala navedenu ulogu te pokazala zavidno znanje materije. I ovdje je, kao i na prethodnoj radionici, bilo neobično vidjeti inače vrlo živahnu djecu, koju je teško usmjeriti na jednu aktivnost, da su bila iznimno mirna i posvećena radu tijekom radionice, a navedena atmosfera prikazana je na Slici 14.

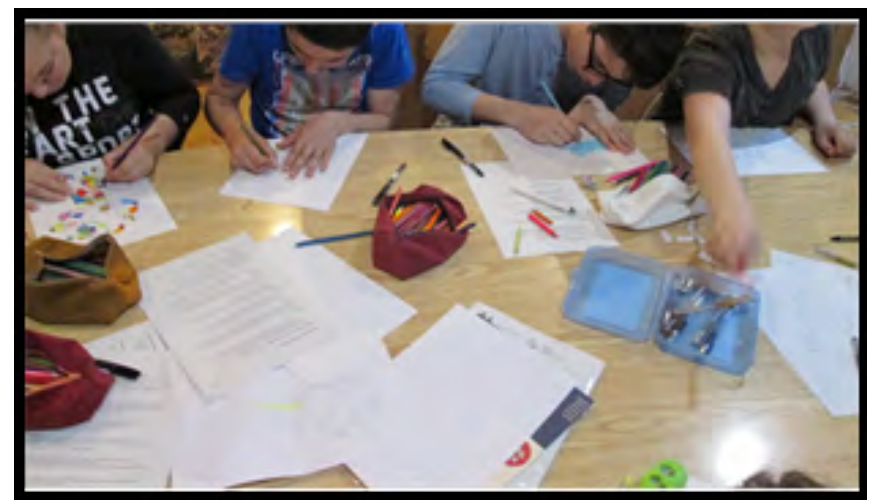

Slika 14. Atmosfera s radionice 
Zamijećeno je da većina djece tijekom stacionarne obrade voli bojiti gotove predloške iz bojanki za odrasle, koje im pribavljaju odgojitelji, što može objasniti i velik interes za radionice fraktalnog crteža. S obzirom da ova metoda uz aspekt bojenja ima i značajno djelovanje putem korištenja linije koje kod gotovih bojanki izostaje, primjena iste otvara mogućnost izrade vlastitih personaliziranih bojanki, što je zahtjevniji zadatak, ali ima i višestruke koristi poput stjecanja nove vještine koja korisno djeluje na naše kognitivne funkcije i jača kreativni aspekt.

Djecu je za ulazak u proces crtanja i dovršenje crteža najviše motivirala znatiželja za dobivanjem informacija iz njihova crteža, koje su im u osnovnim crtama dane nakon dovršetka procesa s naglaskom na potencijale koje mogu razviti, ali i mogućnosti korekcije svojeg stanja i funkcioniranja kojim nisu zadovoljni, a koje ću u kratkim crtama iznijeti prikazima slučajeva. Ovdje napominjem da se ne radi o cjelovitoj dijagnostici i korekciji, za koje je potreban veći broj radova, više vremena i manji broj sudionika, već se radi o analizi i korekciji trenutnog stanja, što je prilagođeno planiranom broju radionica i vremenskom okviru predviđenom za njihovo održavanje.

Kod pojedinaca je zapažen izrazit umjetnički potencijal, što se može vidjeti i na primjeru korekcijskog crteža jednog mladića prikazanog na Slici 15, koji izgleda poput glave nekog lika iz crtanog filma, a nastao je spontano tijekom crtanja apstraktne forme korekcijskog crteža. Iz razgovora s navedenim mladićem, dobivena je informacija da je oduvijek volio crtati, međutim, u posljednje je vrijeme to potpuno zapostavio. Iskazao je da su ga ove radionice potaknule da ponovno počne crtati, što se događa mnogima koji su prakticirali tu metodu. Mnoge osobe koje ranije nisu pokazivale umjetničke sklonosti, nakon fraktalnog crtanja počele su otkrivati svoje talente slikanjem ili pisanjem poezije, o čemu svjedoče brojni primjeri u knjizi „Izvornik fraktalne mudrosti ili nov pogled na naše mogućnosti" (Komov i Polujahtova, 2014).

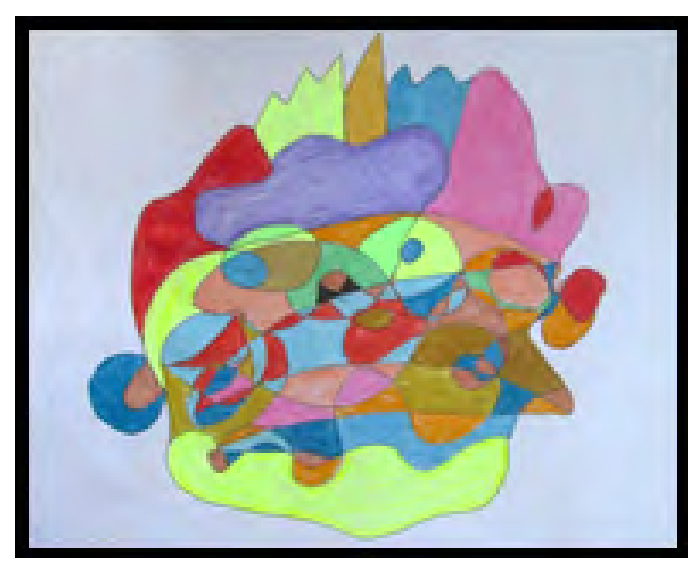

Slika 15. Primjer korekcijskog crteža mladića s crtačkim talentom

Tijekom održavanja radionica zamijetila sam da su djeca najveći strah i otpor imala prema izradi fraktalnog crteža podrške s motivom anđela ili drveta. Radilo se o crtežu na kojemu je bilo zadano nacrtati zamišljen motiv zatvorenim očima, što im se činilo nemogućim, međutim, nakon podrške i ohrabrenja da se upuste u sam proces crtanja, rezultat ih je oduševio i upravo su ih navedeni crteži najviše privlačili. Zanimljiva je činjenica da su sva djeca izabrala motiv drveta, koji im se činio manje zahtjevnim, a dva primjera takvih radova prikazana su na Slikama 16 i 17. 


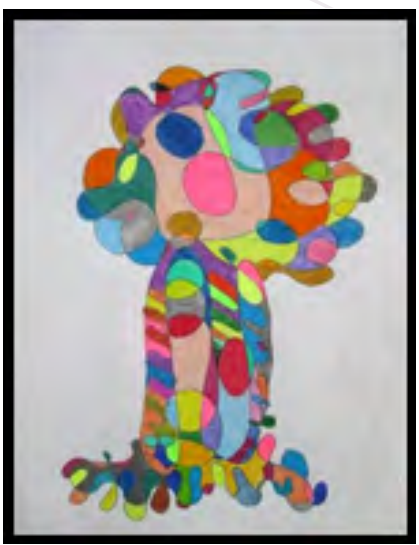

Slika 16. Fraktalni crtež podrške I

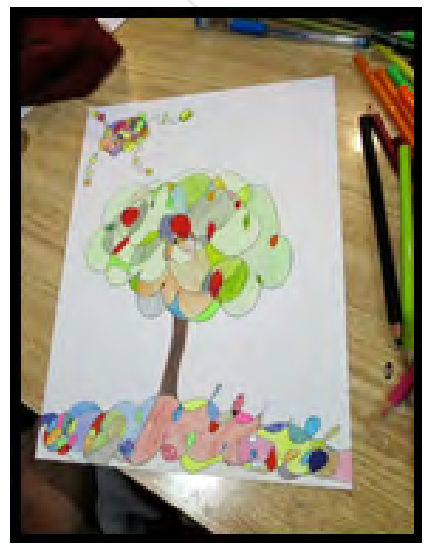

Slika 17. Fraktalni crtež podrške II

Obradom evaluacijskih upitnika dobiveni su sljedeći rezultati:

Zbog ranije navedenih specifičnosti (fluktuacije korisnika, odsustva radi dovršenja obrade ili prekida iste, hospitalizacija, odnosno boravka u školi i ostalih aktivnosti), već je spomenuto da su na radionicama najčešće bile miješane skupine sudionika koji su izradili dijagnostički crtež i nastavljali dalje s edukacijom, te onih koji su tek došli u skupinu i kretali su od osnova.

Najviše sudionika prema popunjenim evaluacijskim upitnicima (ukupno 27), bilo je prisutno na I. radionici, zatim slijedi II. radionica sa 17 popunjenih upitnika, te III. radionica sa samo osam popunjenih upitnika. Prosječna popunjenost upitnika svih triju radionica bila je 17.

Očekivanja od radionica prosječno je imalo sedmero anketiranih, dok je većina (ukupno 14) bila bez očekivanja.

U prosjeku se 12 sudionika prije radionice osjećalo dobro, jedan loše, a četiri neutralno. Tijekom radionice prosječno 16 ispitanih sudionika iskazalo je da im je bilo zanimljivo, dok u prosjeku jedna osoba nije imala određen stav. Nakon radionice prosječno se 15 ispitanika osjećalo ugodno i opušteno, a dvoje nelagodno i napeto.

Sam proces crtanja za većinu sudionika (prosječno 14 po radionici) bio je opuštajući, dok je za prosječno jednu osobu bio nelagodan, 1,3 imalo je neutralan osjećaj, a 0,7 ih je izjavilo kako im je bilo teško crtati i živciralo in je izvlačenje pojedinih boja. Nelagodu i poteškoće najveći broj djece osjećao je u II., zahtjevnijoj radionici.

Prosječno je 11 djece iskazalo da im se na radionicama sve svidjelo, a pojedinci su navodili da im se nije svidjelo bojenje malih polja, puno bojenja, izvlačenje istih boja.

U prosjeku je većina ispitane djece (ukupno 16) iskazala da će nastaviti izrađivati fraktalne crteže, dok se njih četvero izjasnilo: „ne znam". Od osmero djece koja su popunjavala upitnike na posljednjoj radionici, sva su djeca iskazala da im se svidio način vođenja radionice, dok se sama radionica svidjela svima osim jednom djetetu iz III. skupine. Sva anketirana djeca potvrdno su odgovorila na pitanje vide li mogućnost primjene te metode u svom životu. 
Zapazila sam da su prve dvije skupine bile zainteresiranije za radionice i aktivnije su sudjelovale u njima te su djeca djelovala optimističnije i veselije od posljednje skupine u kojoj je nazočilo nekoliko pojedinaca s izrazito depresivnom simptomatologijom i skupina je djelovala manje povezano od prethodnih dviju. Upravo je u posljednjoj grupi, u prosjeku, najviše djece iskazalo nelagodu tijekom izrade fraktalnog crteža i nakon radionice. Ranije navedeno upozorava na činjenicu da ta metoda neće jednako djelovati na svaku osobu, te da će nekima biti interesantna, zabavna i opuštajuća, a drugima prezahtjevna i nelagodna, bez obzira na njezino pojednostavnjivanje popustljivim programom. Međutim, temeljem dosadašnjeg iskustva, ipak se radi o pojedincima u grupi, te i dalje prednjače pozitivne reakcije, što je moguće zapaziti i u sljedećim komentarima.

Dojmovi polaznika navedeni u evaluacijskim upitnicima:

— "Svidjela mi se tehnika i radionica i rado bih da se održi još takvih radionica."

— "Sve mi se svidjelo, posebno crtanje novih stvari i saznavanje boja."

— "Na radionici mi se svidio mir."

— "Svidjelo mi se crtanje, ali mi je bojenje bilo teško posebno malih polja."

— "Svidjelo mi se crtanje zatvorenih očiju."

— "Svidio mi se chill."

— "Sve mi se svidjelo osim napetosti i čudnog osjećaja u prostoriji."

— "Svidjela mi se opuštena atmosfera."

— "Svidjelo mi se što je zanimljivo, a nije mi se svidjelo bojenje."

U nastavku slijedi prikaz dvaju slučajeva:

\section{PRIKAZ SLUČAJA 1 - djevojčica P., 12 godina}

Djevojčica je na prvoj radionici bila šutljiva, pasivna i nemotivirana za rad, premda je željela biti prisutna. Iz njezine anamneze doznaje se da ju je majka zanemarivala i sniženih je intelektualnih sposobnosti.

Prvi crtež koji je izradila prikazan je na Slici 18 te je analiziran na temelju ranije spomenutog ključa koji je razradila autorica metode, odnosno putem pozicije crteža na papiru, svojstva linije, veličine polja, učestala pojavljivanja određenih boja, kao i kvalitete i intenziteta boje. Navedene kombinacije elemenata upozoravale su na jaku emotivnost, potrebu za ljubavlju i pažnjom, te prisustvo velikih trauma u životu djevojčice, kao i nespremnost da se s njima suočava, što je izuzev samih svojstava crteža pokazao i njezin pristup u radu. Djevojčici je, nakon početnih uputa o načinu bojenja, koje nije mogla slijediti (bojila je nemarno i pokrivala istom bojom nekoliko polja odjednom, što u ovoj metodi nije dopušteno), dopušteno raditi najbolje što može i kako će se najugodnije osjećati jer je isto i osnovni princip metode, osobito u radu s djecom. U kratkoj analizi trenutnog stanja djevojčici je, na temelju dominantnih karakteristika elemenata fraktalnog crteža, ukazano na njezinu senzibilnost i emotivnost, te potrebu da se nekim medijem, koji bi je mogao inspirirati i potaknuti njezinu maštu, kreativno izrazi. Na temelju nakupljanja određenih boja u velikim poljima djevojčici je rečeno da posjeduje dosta nakupljene fizičke energije koju bi trebala 
kanalizirati nekom fizičkom, odnosno sportskom aktivnošću. Za jačanje spremnosti rješavanja problema i učinkovitije nošenje s njima, sugerirano joj je da određenu boju, koja predstavlja životne poteškoće, u korekcijskom crtežu smjesti u manja polja u manjoj količini.

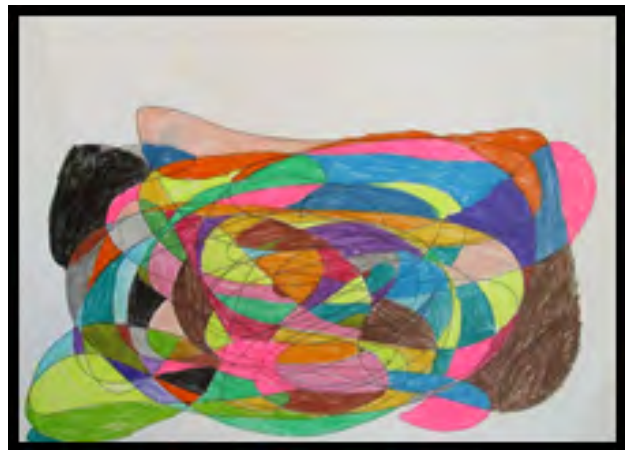

Slika 18. Dijagnostički crtež

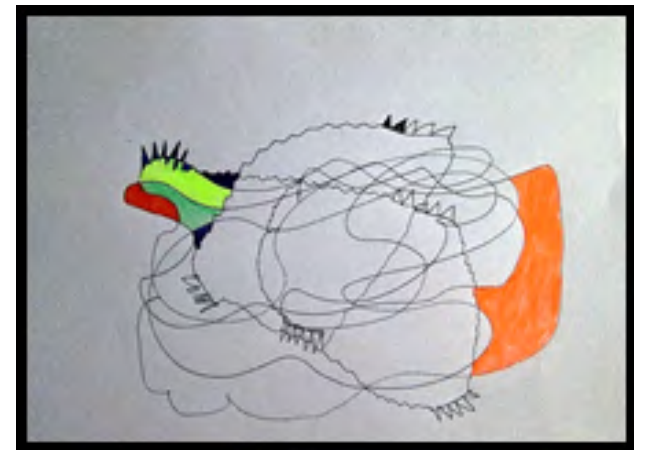

Slika 19. Korekcijski crtež

Drugi korekcijski crtež prikazan na Slici 19, djevojčica je verbalizirala kako želi raditi, te je sama izabrala teži način crtanja uz ubacivanje elementa cik-cak, odnosno špice. Dobila je uputu smanjiti crtež i promijeniti liniju u odnosu na dijagnostički, kao i informaciju kojim bojama obojiti veća, odnosno manja polja, uz napomenu da pažljivo oboji svako polje ne prelazeći njegove linije. Premda je iz crteža razvidno da je većinu rečenoga poštovala i sasvim joj je dobro krenulo, ubrzo je odustala i rekla da ne može dalje bojiti. Moguće je da je djevojčica intuitivno osjetila da u danom trenutku još nije spremna na neke promjene i to je potrebno prihvatiti. Rečeno joj je da je to u redu, da je bez obzira što nije dovršila crtež pokazala veliku hrabrost te slobodno može ostati na radionici, što je ona i učinila. U njezinu slučaju može se reći da je i malo puno, a budući da je naučila pravila metode, istu će moći koristiti kada bude spremna.

Na posljednjoj radionici prilikom izrade fraktalnog crteža podrške koji je trebao predstavljati potporu u teškim životnim situacijama, djevojčica je s lakoćom i radošću izrađivala crtež prikazan na Slici 20, te se njezino raspoloženje tijekom same radionice vidno mijenjalo. Od djevojčice s prve radionice bez ikakve mimike lica i potpuno beživotne energije, sada se počela smijati, ulaziti u interakciju s drugom djecom, a odgojiteljica je zamijetila i značajne promjene u njezinu ponašanju sljedećih dana na način da je postala aktivnija i motiviranija za rad i samoinicijativno sudjelovala u aktivnostima koje je ranije izbjegavala.

U samom crtežu podrške zamijećen je značajan pomak na način da je lakše slijedila pravila, prisutna je bolja koncentracija i sposobnost bojenja u odnosu na prvi crtež, a primjenjivala je veselije i vedrije boje. Kod djevojčice je pozitivan pomak vjerojatno učinio i konkretan motiv drveta za razliku od prethodnih apstraktnih formi crteža, te veća sloboda kad su u pitanju pravila.

Tijekom redovitih supervizija i konzultacija s autoricom metode, kada se analiziraju pojedinačni slučajevi, obrazložila je vidljiv pomak kod djevojčice na način da je doživjela nešto poput kvantnog skoka prilikom izrade crteža drveta kao jedne umjetničke i slobodnije forme, što je zaključila iz drastične promjene u načinu crtanja, odnosno korištenju linija i boja te bolje motoričke sposobnosti bojenja, s čime bih se osobito složila. Preporuka u slučaju te djevojčice bila je da svakako nastavi izrađivati umjetničke crteže. 


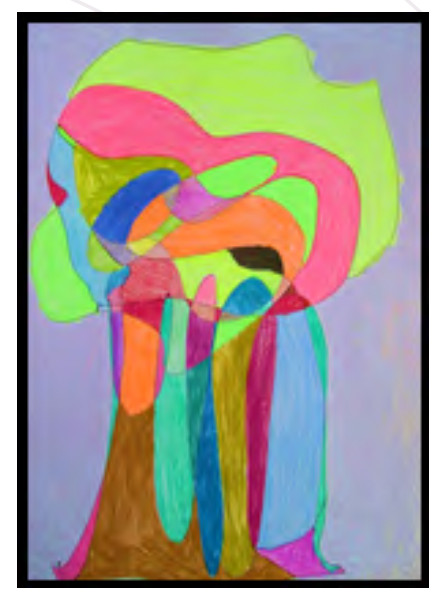

\section{Slika 20. Fraktalni crtež podrške}

\section{PRIKAZ SLUČAJA 2 - dječak M., $15 \mathrm{~g}$.}

Dječak je s metodom bio upoznat odranije i pokazao je veliku motivaciju u radu te je svojim vedrim duhom uveseljavao cijelu skupinu. Iz anamneze je poznato da dječak odrasta u lošim socioekonomskim prilikama, žrtva je očeva zlostavljanja te je boravio s majkom u sigurnim kućama.

Kod ovog dječaka specifični su bili njegovi neobični komentari i reakcije na prvi dijagnostički crtež koji je izradio, prikazan na Slici 21. Navedeni crtež stalno je pokazivao, promatrao i izjavljivao da mu je toliko lijep i da misli da se zaljubio u nj. Neobična reakcija dječaka na crtež prokomentirana je i s autoricom metode tijekom redovitih supervizija, koja je nakon vertikalne rotacije crteža (prikazano na Slici 22) u vanjskoj konturi crteža uočila profil bake i temeljem elemenata analize ispričala da se u dječakovu crtežu iz njegova nesvjesnog pojavio sadržaj vezan za najranije djetinjstvo, odnosno odrastanje uz baku koja ga je jako voljela i brinula se o njemu u toj dobi. Dječak na svjesnoj razini nije došao u kontakt s navedenim sadržajem, međutim, u njemu se pojavila emocija ugode koju je povezao sa samim crtežom. Ovdje treba napomenuti da se radi o interpretaciji autorice metode na temelju intuitivnoga i empirijskog tumačenja. Vještina analize fraktalnih crteža, kao što je već ranije navedeno, usavršava se proučavanjem što većeg broja fraktalnih crteža, te istom nije moguće ovladati isključivo poznavanjem teorije i fraktalnog ključa. Iz osobnog iskustva, te poznavanja načina rada i analiza dijagnostičkih crteža autorice metode, mislim da je crtež moguće protumačiti na takav način.

Bez obzira na činjenicu da dječak nije imao ranije navedene informacije i saznanja, sam proces crtanja i promatranja njegova rada izazvao je u njemu osjećaj zadovoljstva, što ukazuje na značajan potencijal metode kad je posrijedi ublažavanje stresnih situacija kao što je dijagnostička obrada, odnosno boravak djece u institucijskim uvjetima. Dječak je i sam verbalizirao da osjeća dobrobit metode otkada je istu počeo primjenjivati, na način da osjeća kako ga izrada fraktalnih crteža smiruje i veseli i zato ih planira nastaviti raditi.

Na dječakovu crtežu zapažen je, putem ranije obrazložene analize, jedan element koji temeljem pozicije na crtežu i dominantne boje upozorava na događaj iz prošlosti koji je na nj iznimno dramatično djelovao, a isti je potisnuo i na neki način odcijepio od sebe, što je jasno vidljivo na crtežu. Dječaku je rečeno da su na crtežu vidljivi elementi koji mogu ukazivati na talent za pisanje 


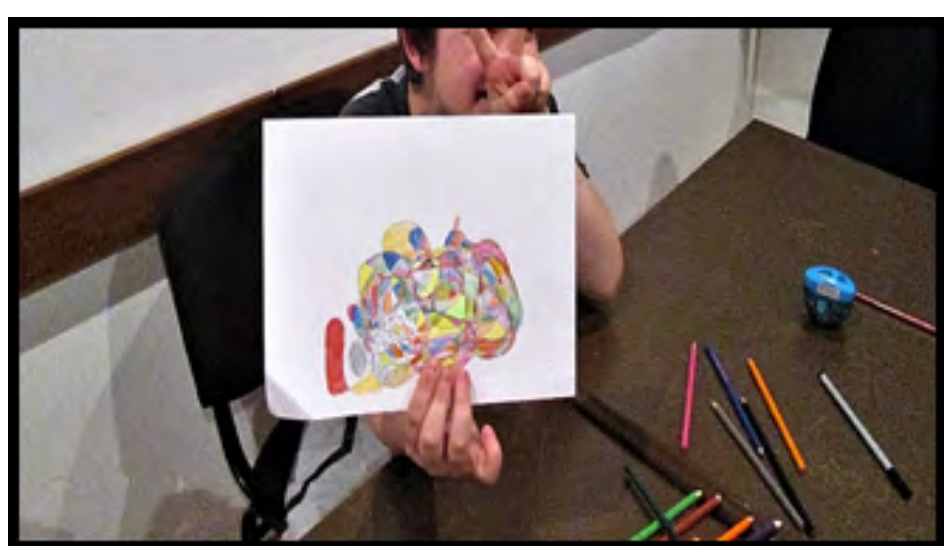

Slika 21. Dječak s ponosom pokazuje svoj crtež

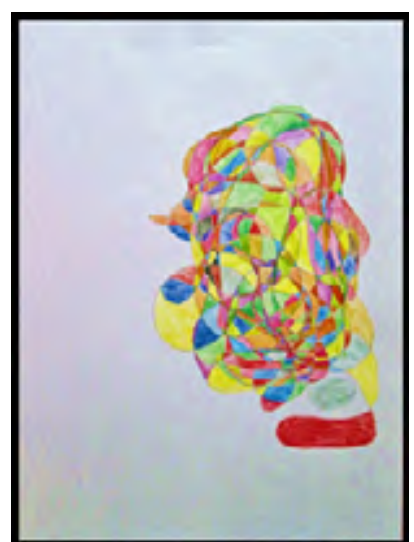

Slika 22. Crtež s profilom bake

i prenošenje informacija i potaknut je pokušati istražiti i razviti vještinu pisanja, čime se oduševio. Sugerirano mu je da se u korekcijskom crtežu koristi suprotnim linijama od primijenjenih na dijagnostičkom crtežu da bi unio više odlučnosti, upornosti, dosljednosti i zauzimanja za sebe, te proširi crtež uz upute o optimalnoj količini i poziciji pojedinih boja.

Nakon završetka radionica (i nakon poticaja da razvija svoj spisateljski talent) dječak je autorici metode Tanziliji Polujahtovoj, napisao pismo zahvale prikazano na Slici 23, koje joj je uručeno na njegovu molbu tijekom njezina gostovanja u Hrvatskoj krajem 2017. godine.



Slika 23. Pismo autorici metode

Dječakovi komentari tijekom radionice:

— "Jako mi se sviđa moj crtež, zaljubljen sam u njega."

— "Nakon radionice crtanja fraktalnih crteža bolje sam spavao." 


\section{Radionice održane u Odgojnom zavodu Turopolje}

Održana su dva ciklusa radionica u razdoblju od 11. srpnja do 15. kolovoza 2017. u kojima su, tijekom obavljanja odgojne mjere upućivanja u odgojni zavod, sudjelovala 23 mladića u dobi od 15 do 20 godina.

Izazovi navedenih radionica bili su vezani uz motivaciju mladića starije životne dobi i intenzivnijih poteškoća, između ostalog i zlouporabe psihoaktivnih tvari, prilagodbu radionica različitoj strukturi mladića u smislu velikih razlika u dobi, osobnosti, intelektualnim sposobnostima, psihičkim i zdravstvenim poteškoćama. Dodatni izazov bilo je uvođenje odluke o zabrani pušenja tijekom održavanja radionica, što je kod većine mladića dodatno potenciralo napetost i nervozu.

Kao i u prethodno prikazanoj ustanovi, u Odgojnom zavodu također je bila prisutna česta fluktuacija, na način da su pojedini mladići zbog sudskih rasprava, stegovnih postupaka ili otpusta bili spriječeni dolaziti na sve radionice, tako da je svaki put bilo novih sudionika i često se tijekom jedne radionice provodilo više različitih edukacija. Bilo je i pojedinaca koji nisu bili zainteresirani za fraktalne crteže, već su dolazili s namjerom sabotiranja radionice. S obzirom da im to ipak nije uspijevalo, budući da se zainteresirani mladići nisu dali smesti, vrlo su brzo napuštali prostoriju. Velik odaziv i interes mladića za radionice, kao i njihov aktivan angažman, upravo je zbog svih ranije navedenih razloga bio veliko pozitivno iznenađenje.

Mladiće je, kao i kod većine prijašnjih sudionika radionica, na dovršenje njihovih crteža najviše motivirala mogućnost dobivanja informacija iz crteža, a koje su ih dodatno potaknule da nastave s primjenom metode. Primjer jednog dijagnostičkog crteža prikazan je na Slici 24, iz kojega se na temelju karakteristika linije i kombinacije boja, zapaža da autor crteža ima potencijal za egzaktne znanosti, dobro funkcionira u čvrsto zadanoj strukturi, osobito iz razloga što svoje frustracije često ventilira na neprimjerene načine nekontroliranom agresijom i ispadima bijesa. Forma ukazuje i na osobu nesklonu kompromisima. Mladić je potvrdio da mu, unatoč tomu što mu se ne sviđa biti zatvoren, takva struktura odgovara jer ga prisiljava na promjene koje sam ne bi imao snage učiniti. U korekcijskom crtežu usmjeren je na optimalno unošenje pojedinih boja te primjenu suprotnih linija od primijenjenih na ovom crtežu, da bi razvio osobine fleksibilnosti i tolerancije. U odnosu na primjereno izbacivanje nakupljenih frustracija i potrebu za strukturom i disciplinom, sugeriran mu je vojnički režim vježbanja.

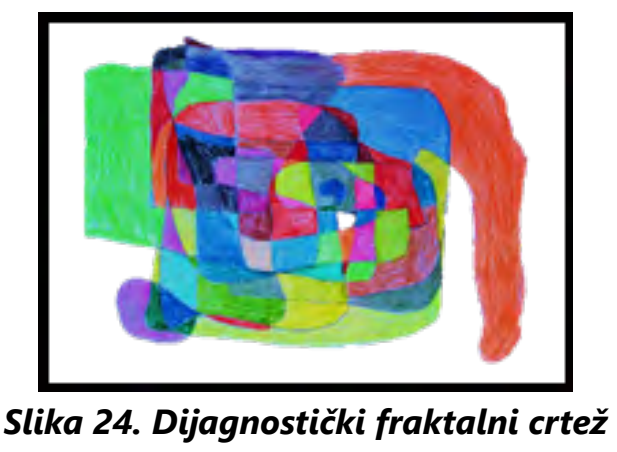

Izuzev ranije spomenutog interesa za dijagnostičke crteže, najveće iznenađenje bio je velik interes za izradu umjetničkih fraktalnih crteža, nakon početne sumnje i straha zbog nepovjerenja 
u vlastite sposobnosti. Kada je mladićima bio loš dan i nisu bili motivirani raditi korekcijske crteže, predloženo im je da naprave umjetnički, odnosno fraktalni crtež podrške s motivom svojih sretnih brojeva, inicijala ili nekih drugih simbola koji njima nešto znače. Na taj način u rad su se uključivali i mladići koji ranije nisu bili dovoljno motivirani. Na Slici 25 prikazan je primjer crteža mladića iz Splita koji je na svakoj radionici započeo raditi fraktalni crtež, ali je ubrzo odustajao i bio potpuno demotiviran za rad. Umjetnički crtež sa simbolikom njegova rodnoga grada prikazan na toj slici, jedini je crtež koji je uspio dovršiti i trudio se pažljivo ga obojiti, što je za nj bio velik pozitivan iskorak.



Slika 25. Primjer improvizacije

Obradom popunjenih evaluacijskih upitnika dobiveni su sljedeći rezultati:

Najviše sudionika, prema popunjenim evaluacijskim upitnicima (ukupno 18), bilo je prisutno na I. radionici (odnosno, izradilo je dijagnostički fraktalni crtež), a prosječna popunjenost upitnika svih triju radionica bila je 10.

Pozitivna očekivanja od radionice, u prosjeku je imalo troje anketiranih (pojedinci su navodili da su imali očekivanja: "da će se veseliti i naučiti nešto novo"), a bez očekivanja je bila većina (u prosjeku osmero).

Prosječno se prije radionice dobro osjećalo osmero anketiranih sudionika, jedan loše, a jedan neutralno. Tijekom radionice većina (prosječno osmero) sudionika iskazala je da im je bilo zanimljivo; jedna osoba nije imala određen stav, dok je u prosjeku jednom ispitaniku bilo dosadno. Nakon radionice u prosjeku se osmorica mladića osjećala ugodno i opušteno, jedan nelagodno i napeto, a jedan sudionik osjećao se isto kao prije.

Tijekom crtanja, u prosjeku se osmero ispitanika osjećalo opušteno i ugodno; jedna osoba rekla je da ju je živciralo izvlačenje određenih boja; 0,7 sudionika iznenadio je izgled njihova crteža, a 0,3 iskazalo je nelagodan osjećaj (ponovno je nelagodan osjećaj povezan s II. radionicom).

Devetorica anketiranih mladića iskazala je da im se sve svidjelo na radionicama, pojedinci su navodili i što im se konkretno svidjelo, a jedan je mladić rekao da mu se ništa nije svidjelo.

Prosječno je osmorica mladića iskazala da će nastaviti izrađivati fraktalne crteže, dok su dvojica izjavila da ne znaju. 
Od osmorice mladića koji su popunjavali upitnike na posljednjoj radionici, šestorica je iskazala da im se svidio način vođenja radionice, a dvojica nisu imali mišljenje o tome, dok se sama radionica i metoda svidjela svima. Na pitanje, vide li mogućnost primjene ove metode u svojem životu, šestorica mladića odgovorila je potvrdno, a dvojica su odgovorila: „možda”.

Mladići su u razgovoru tijekom radionice iskazali da im je puno značila i komunikacija koja se otvarala tijekom rada, kao i pozitivna i opuštena atmosfera na radionicama. Odgojitelji su zamijetili da mladiće izrada fraktalnih crteža smiruje, a i sami mladići potvrdili su navedeno i izrazili želju za ponovnim održavanjem radionica. Odgojiteljica, koja je i sama završila edukaciju za stručnjake, nastavila je raditi fraktalne crteže s mladićima koji su pokazali motivaciju.

S obzirom da su u zavodskim uvjetima mladići dostupni tretmanu i tijekom izvršenja mjere stječu čitav niz životno korisnih vještina, isto tako su i učenjem ove metode dobili koristan alat koji im može pomoći u učinkovitijem nošenju sa stresnim situacijama.

Komentari polaznika radionica navedeni u evaluacijskim upitnicima:

— "Sve mi se svidjelo."

— "Sviđalo mi se bojiti."

— "Svidjelo mi se što sam naučio nešto novo."

— "Svidjela mi se radnja na radionici i djelatnici radionice."

U nastavku slijede prikazi slučajeva:

\section{PRIKAZ SLUČAJA 3 - mladić J., 15 godina}

U ovom slučaju prikazan je rad s romskim mladićem koji je bio zatvoren u komunikaciji, no aktivno je sudjelovao u svim radionicama.

Prvi dijagnostički crtež prikazan na Slici 26 potpuno je dovršio, no nije se previše trudio oko bojenja. Iz crteža je, na temelju analize osnovnih elemenata fraktalnog crteža, osobito linije, uočena karakteristika nesigurnosti i nedostatka samopouzdanja, te je mladić dobio uputu za harmoniziranjem tog stanja osobito putem sigurnijeg iscrtavanja linije na idućem crtežu.

Tijekom izrade drugoga, korekcijskog crteža prikazanoga na Slici 27, mladić je lakše slijedio upute i unio određene promjene u crtež (proširio konturu crteža, promijenio način izvođenja linije,



Slika 26. Dijagnostički crtež



Slika 27. Korekcijski crtež 
unio življe boje i pojačao pritisak prilikom bojenja u odnosu na prethodni crtež) te je vidljiv veći trud i bolja motorička sposobnost prilikom bojenja crteža, premda ga nije dovršio s obzirom da je iziskivao više vremena.

Na trećoj radionici dogodio se njegov najveći iskorak. S obzirom da mladići borave u zatvorenim uvjetima, predložila sam im izradu umjetničkog fraktalnog crteža podrške s motivom ptice slobode. Nakon početnog straha i nesigurnosti da neće moći napraviti sliku zatvorenih očiju, kada se uz podršku odvažio izraditi crtež ptice i nakon što je vidio kakav prekrasan crtež je napravio, $s$ oduševljenjem je isti obojio. Najponosniji je bio nakon pohvale ostalih mladića. Na navedenom crtežu, prikazanome na Slici 28, lako je zamijetiti značajan pomak u finoj motorici, od jasnoće i sigurnosti same linije do velikog truda i finoće u načinu bojenja, a najznačajnije od svega je sama činjenica o učinku te spoznaje na jačanje samopouzdanja ovog mladića.

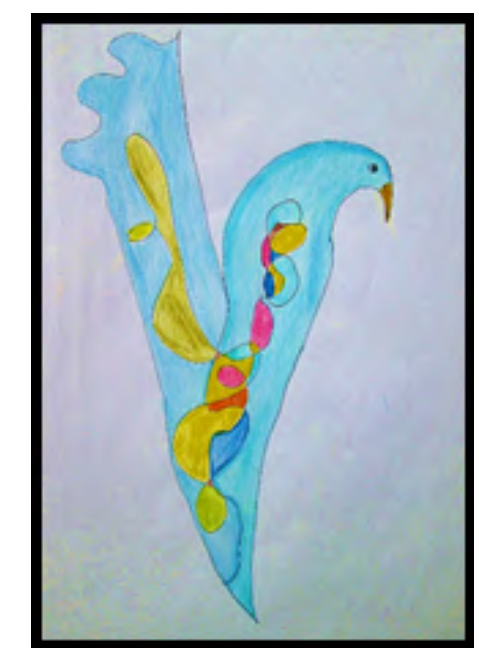

\section{Slika 28. Umjetnički fraktalni crtež — ptica slobode}

\section{Radionice održane u Odgojnom domu Bedekovčina}

Održan je jedan ciklus radionica u periodu od 5. listopada do 30. listopada 2017., u kojima su sudjelovale četiri djevojke u dobi od 14 do 16 godina. Djevojke su bile izrazito rizična, promiskuitetna ponašanja, sklone bjegovima i konzumaciji psihoaktivnih tvari.

Tijekom provedbe radionica u ustanovi je bilo smješteno ukupno osam djevojaka od kojih je polovica bila u bijegu. Djevojke, koje su prihvatile sudjelovanje u radionicama, bile su otvorene za suradnju i komunikaciju, a odgojitelji su iskazali da djevojke inače odbijaju sudjelovanje u bilo kakvim aktivnostima i iznenadio ih je interes za održane radionice. Ozračje s jedne od radionica prikazano je na Slici 29. 


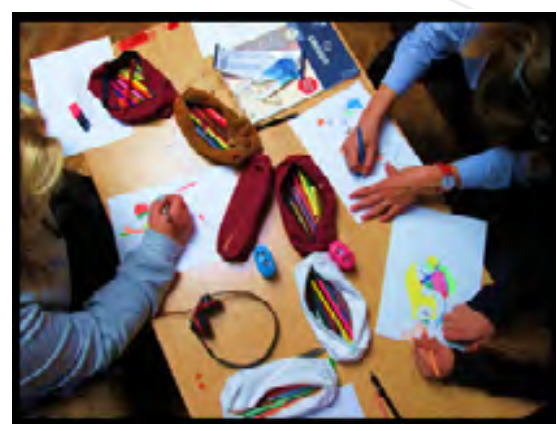

Slika 29. Atmosfera s radionice



Slika 30. Primjeri improvizacija - fraktalna ogrlica

Najveći izazov ovih radionica bila je nemogućnost planiranja s obzirom da se nije moglo znati koliko će djevojaka biti u bijegu, a bilo je upitno i njihovo sudjelovanje u planiranim aktivnostima. Djevojke su također bile promjenjiva raspoloženja, dosta nemirne i nervozne, najčešće nisu imale dovoljno motivacije i strpljenja obojiti velike crteže A4 formata, te je bilo potrebno improvizirati i osmisliti aktivnosti koje bi im bile interesantne i u kojima bi vidjele osobnu korist. Na taj način nastala je ideja o fraktalnim ogrlicama prikazanim na Slikama 30 i 31, koje su izrađene od tvrdog kartona s vrpcama od tkanine, na koje su djevojke lijepile male fraktalne crteže koje su same izradile. Navedene fraktalne minijature zahtijevale su također ulaganje truda, ali manje vremena za dovršenje cjelokupnoga rada, što je djevojke znatno više motiviralo. Dodatno ih je motivirala i praktična primjena njihova rada, odnosno činjenica da su samostalno izradile ogrlice koje mogu nositi u školu. Efekt dobrobiti fraktalnog crtanja time nije izostao, s obzirom da su mogle osjetiti djelovanje metode opuštajućim osjećajem i fokusom na aktivnost kojom se bave, a također su vježbale finu motoriku sitnim potezima na malim formatima.

Na posljednjoj radionici dogodila se i jedna zanimljiva situacija kada je jedna djevojka ušla u konflikt s odgojiteljicom. Tijekom radionice razgovarali smo o njezinu neprimjerenu ponašanju i mogućnosti drukčije reakcije te je naposljetku iskazala žaljenje što se tako ponijela. Predloženo joj je da u znak isprike odgojiteljici izradi ogrlicu, što je ona učinila i poklonila ogrlicu odgojiteljici u znak pomirenja. Ogrlica pomirenja prikazana je nas Slici 31, a njezina simbolika najbolje pokazuje što su fraktalni crteži i čudesan način na koji djeluju.

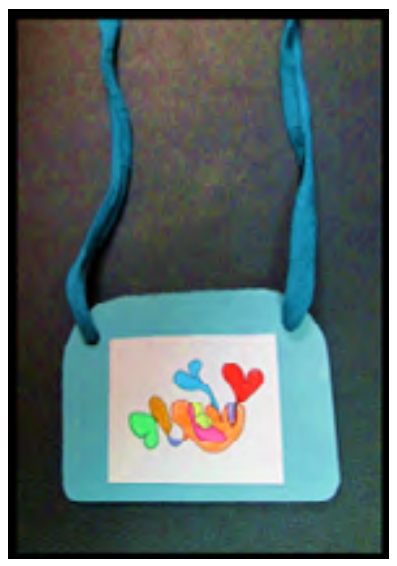

Slika 31. Ogrlica pomirenja 
Analizom popunjenih evaluacijskih upitnika (u prosjeku tri tijekom svih triju radionica) dobiveni su sljedeći rezultati:

Prosječno su se dvije anketirane djevojke dobro osjećale prije radionice, dok se jedna osjećala loše. Tijekom radionice 2,3 anketiranih izjavilo je da im je bilo zanimljivo, dok se 0,3 osjećalo neutralno. Nakon radionice u prosjeku se 2,3 djevojaka osjećalo ugodno i opušteno, a 0,3 isto kao i prije radionice.

U prosjeku je broj djevojaka koje su imale pozitivna očekivanja, bio jednak broju onih koje nisu imale nikakva očekivanja od radionice.

Na pitanje, kako su se osjećale tijekom izrade fraktalnog crteža u prosjeku su dvije anketirane djevojke izjavile da im je bilo ugodno i opušteno, a prosječno jednoj sudionici bilo je zanimljivo. Ovdje se ponovio rezultat kao is prethodnih radionica te je ponovno Il. radionica, kao najzahtjevnija, svima bila najmanje ugodna.

Svim ispitanim djevojkama svidio se način vođenja radionica, dok se metoda i sama radionica svidjela dvjema sudionicama, a jedna je imala neutralan stav. Jedna je djevojka potvrdno, jedna negativno, a jedna neutralno odgovorila na pitanje hoće li nastaviti crtati fraktalne crteže. Sve tri anketirane djevojke izjasnile su se da možda vide korist od primjene te metode u svojem životu.

Djevojke su tijekom radionica imale potrebu za razgovorom te kasnije iskazale da su im radionice bile ugodne i korisne upravo zbog opuštene atmosfere $i$ komunikacije uza sam rad.

Komentari djevojaka o održanim radionicama :

— "Nema toga što mi se nije svidjelo."

— "Sve mi je bilo pre super."

— "Svidjelo mi se dugotrajno bojanje."

\section{Rezultati projekta}

Tijekom Projekta educirano je 80 osoba (16 stručnjaka i 64 djece i mladih).

Polaznici radionica stekli su znanja i iskustvo primjene vrijednog alata koji im može pomoći u osnaživanju vlastitih kapaciteta.

Djeca su nakon radionica dobila kratke skripte s uputama za primjenu metode i prikazom nekoliko jednostavnih vježbi Brain Gyma koje im mogu pomoći kada se osjećaju loše ili imaju problema s učenjem, a također su u kratkim crtama analize dobili smjernice za razvoj svojih potencijala.

$\mathrm{Na}$ temelju analize evaluacijskih upitnika, odnosno samoprocjene polaznika, utvrđeno je sljedeće :

— većina polaznika doživjela je samu metodu zanimljivom i pristupačnom

— većina polaznika iskazala je da se osjeća ugodno i opušteno nakon radionica 
— sudionici su najzahtjevnijom radionicom, na kojoj su se najlošije osjećali, od svih triju održanih ocijenili II. radionicu na kojoj se izrađivao korekcijski fraktalni crtež s kojim je uvedeno više pravila

— stručnjaci su iskazali da vide mogućnost primjene metode u osobnom razvoju i suzbijanju stresa, kao i radu s djecom, a većina djece iskazala je da vidi moguću korist od primjene te metode u svojem životu

— djeci i stručnjacima svidio se način prezentacije metode i izrazili su želju za nastavkom održavanja navedenih radionica.

Nakon dovršenog Projekta 15. studenoga 2017. u Centru za kulturu Prečko u Zagrebu otvorena je izložba radova polaznika radionica kojoj su prisustvovala djeca, sudionici Projekta sa svojim odgojiteljima, što je prikazano na Slici 32, a istu je posjetila i autorica metode prilikom svojega gostovanja u Hrvatskoj (Slika 33).



Slika 32. Otvorenje izložbe



Slika 33. Gostovanje autorice metode (u sredini)

Osobito je bila dirljiva radost djece kada su ugledala svoje izložene radove i brojne posjetitelje izložbe, te na takav način doživjela vrijednost i javnu pohvalu svojeg rada i truda.

Ustanovama koje su sudjelovale u Projektu, doniran je i materijal za izradu fraktalnih crteža da bi djeca mogla nastaviti s primjenom metode.

\section{Zaključci projekta}

Održanim Projektom stekao se uvid kako na primjenu metode fraktalnog crteža reagira populacija djece s problemima u ponašanju radi prilagodbe iste svojim potrebama, te je zaključeno sljedeće:

— potreba za improvizacijom i prilagođavanjem metode interesu djece da bi ih se motiviralo na rad (primjerice, fraktalni crteži s konkretnim motivom djeci su bili interesantniji, smisleniji i bili su motiviraniji i koncentriraniji prilikom njihove izrade) 
— u radu s djecom prijeko je potrebna primjena tzv. popustljivog programa u odnosu na zahtjevna pravila metode, na način da svako dijete radi crtež koliko i kako može, te da se pravila još više pojednostavne, osobito u korekciji koja je i uz pojednostavnjena pravila djeci bila prezahtjevna

— potreba prilagodbe koncepta radionica za različitu strukturu djece unutar grupe, prema njihovim sposobnostima, stupnju znanja o metodi, raspoloženju

- budući da je zapaženo da su hiperaktivna djeca uspijevala održavati koncentraciju i fokus i puna dva sata tijekom izrade fraktalnih crteža, metodu je vrijedno koristiti u radu s djecom koja imaju takvih poteškoća

— kod djece je zamijećena znatno bolja motorička sposobnost crtanja i bojenja nakon nekoliko izrađenih fraktalnih crteža, što je iznimno važno s obzirom da većina djece ima slabo razvijenu finu motoriku, što može biti posljedica prekomjerna korištenja tehnologije poput mobitela i računala

— u pojedinim slučajevima bili su vidljivi trenutni učinci metode velikim pozitivnim iskoracima kako u samom radu tako i ponašanju i raspoloženju djeteta, što je vrijedno daljnjeg istraživanja primjene metode u duljim razdobljima radi postizanja trajnijih promjena

— postoje i ograničenja metode na način da ista različito djeluje na svakoga, tako da kod pojedinaca ne pobuđuje osobit interes, čemu razlog može biti njihova nesklonost umjetničkom izražavanju, nestrpljivost i dosada zbog nerazumijevanja svrhe primjene metode, nelagoda i strah od neuspjeha, napor pri crtanju zbog loše razvijenosti fine motorike, otpor prema novome, autoritetima i pravilima, povodljivost, te nespremnost na promjene

— došlo je do promjene percepcije kod stručnjaka koji rade s navedenom skupinom djece na način da su dobili uvid da postoje još neki načini za motivaciju iste na rad

— stručnjaci koji su sami završili edukaciju stekli su uvid u mogućnosti primjene metode u radu s navedenom dječjom populacijom, od primjene iste kao pomoćnog sredstva u njihovoj dijagnostici do samog tretmana, ali i u osobnom radu radi prevencije sindroma sagorijevanja.

\section{Ostale mogućnosti primjene metode u sustavu socijalne skrbi}

U nastavku rada prikazat ću još neke mogućnosti primjene ove metode iz pozicije socijalnog pedagoga u sustavu socijalne skrbi, gdje sam zaposlena. U svojem dosadašnjem radnom stažu u ovom sustavu zamijetila sam, kako kod sebe tako i kod svojih kolegica i kolega, posljedice pogubna učinka svakodnevne izloženosti visokoj razini stresa na psihofizičko zdravlje. Iz navedenog razloga imala sam potrebu održati antistresni program fraktalnog crtanja za svoje kolegice i kolege, da bismo se međusobno više povezali jednom opuštajućom aktivnošću koja je trebala unijeti malo vedrine i optimizma u svakodnevnu rutinu, te da bismo stekli novu vještinu koja nam može olakšati svakodnevne stresne situacije. 
Slijedi prikaz navedenih radionica, a nakon toga ću predstaviti i dva prikaza slučaja primjene metode fraktalnog crteža dvama segmentima rada socijalnog pedagoga u CZSS-u, odnosno radu s odraslom štićenicom u okviru poslova skrbništva, te radu s djevojkom s problemima u ponašanju.

\section{Antistres radionice za stručnjake centra za socijalnu skrb}

Održana su dva ciklusa radionica u Centru za socijalnu skrb Zagreb — Podružnica Trešnjevka u razdoblju od 3. ožujka do 4. travnja 2017., u kojima je sudjelovala 31 osoba, djelatnici CZSS-a različitih struka (socijalni radnici, psiholozi, socijalni pedagozi i pravnici). Radionice su se održavale jedanput tjedno u trajanju od dva sata.

Tijekom radionica zamijetila sam da se dvorana, u kojoj se inače održavaju teški i izrazito stresni razgovori, transformirala u potpuno drukčiji, vedriji prostor, što su komentirali i sami sudionici, a dio ozračja s radionica prikazan je na Slici 34.

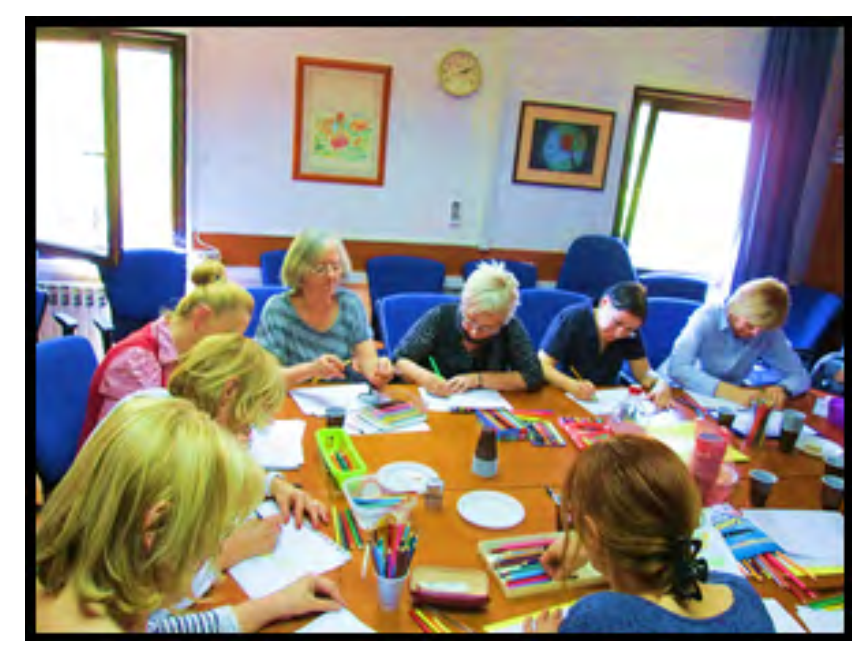

Slika 34. Atmosfera s radionice

$\mathrm{Na}$ temelju analiziranih ukupno 26 popunjenih evaluacijskih upitnika, koje su polaznici dobrovoljno ispunjavali na posljednjoj radionici (za razliku od svih prethodno prezentiranih radionica gdje su se popunjavali upitnici nakon svake održane radionice), utvrđeno je da se 11 anketiranih osoba prije radionice osjećalo dobro, 12 neutralno, a tri su se osobe osjećale loše.

Tijekom radionice 16 sudionika osjećalo se ugodno, devetero ih je opisalo da im je bilo zanimljivo, jedna se osoba osjećala neutralno, dok se nakon radionice najveći broj sudionika osjećao ugodno i opušteno (ukupno 21). Pet osoba osjećalo se jednako kao prije radionice.

Izrada fraktalnog crteža kod 22 sudionika izazvala je osjećaj ugode i opuštenosti, jedna osoba osjećala se nelagodno, jednoj je bilo teško raditi crtež i slijediti pravila, a dvije su se osobe osjećale neutralno.

Na pitanje, mogu li povezati svoj pristup životu s načinom pristupanja izradi fraktalnog crteža, 13 sudionika odgovorilo je potvrdno, jedan negativno, a 12 osoba je odgovorilo da ne zna. 
Svih 26 anketiranih sudionika odgovorilo je da im se svidjela radionica i sama metoda, kao i način prezentacije i vođenja radionice.

Većina polaznika prema navedenim rezultatima pozitivno je reagirala na održane radionice i osjetila opuštajući efekt same metode, te su pokazali velik kreativni potencijal i maštovitost, što se može vidjeti iz njihovih radova prikazanih na slikama 35, 36 i 37.

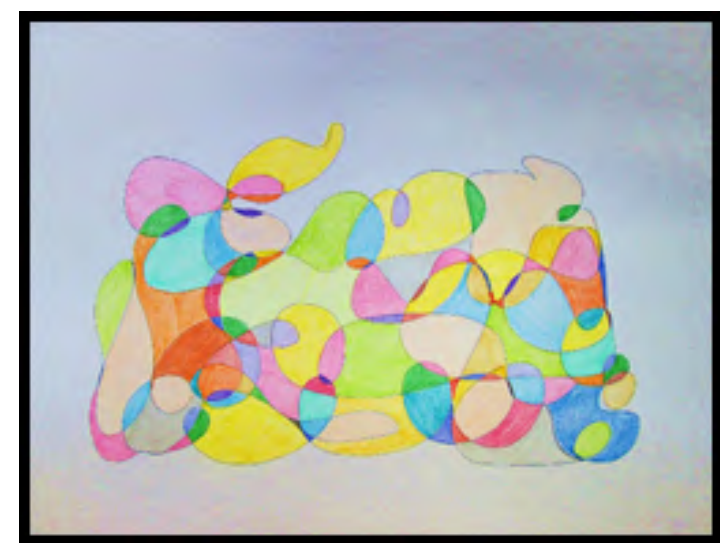

Slika 35. Dijagnostički fraktalni crtež

Neki od komentara i dojmova polaznika radionica:

— "Predlažem održavanje ovakvih radionica bar jednom tjedno."

- "Oduševljena sam."

— "Trebalo bi duže trajati."

- "Ponoviti."

— "Može opet."

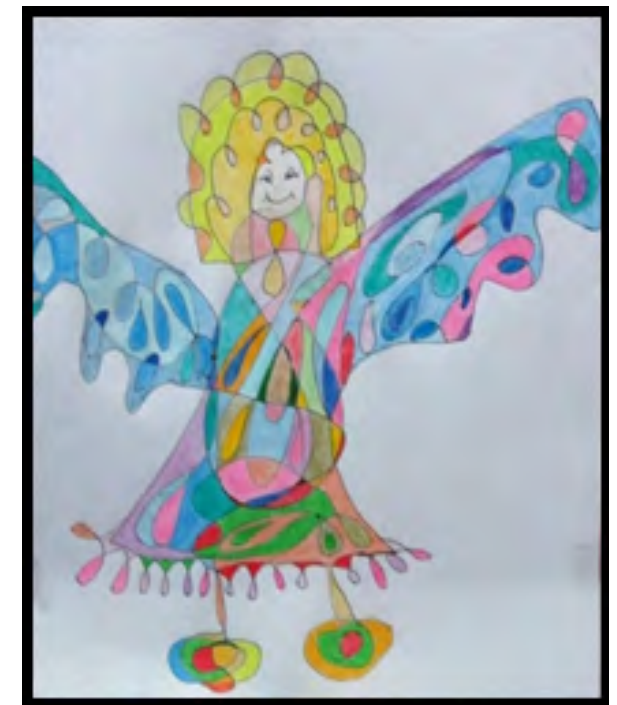

Slika 36. Fraktalni crtež podrške I

- anđeo

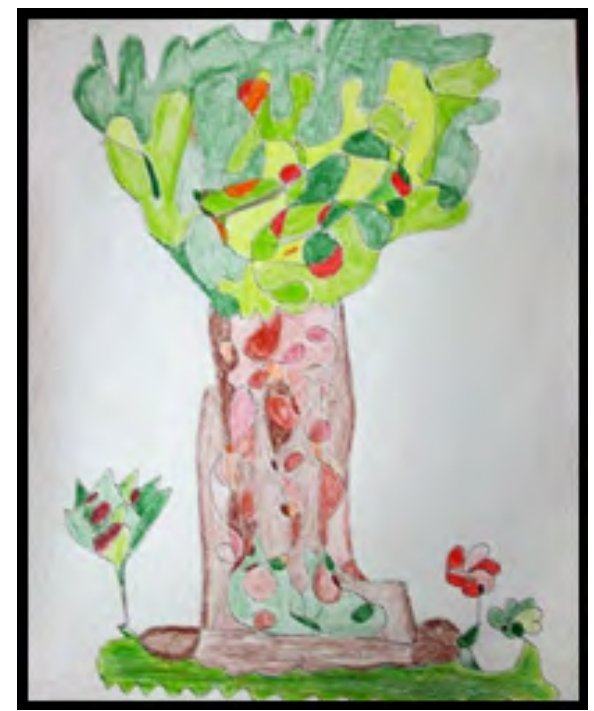

Slika 37. Fraktalni crtež podrške II - drvo 
Održanim radionicama stekao se uvid u mogućnost primjene ove i sličnih metoda u pomagačkim strukama u svrhu podrške i prevencije sindroma sagorijevanja na radnome mjestu.

U nastavku će biti prezentirani prikazi dvaju slučajeva:

\section{PRIKAZ SLUČAJA 4 - rad s odraslom osobom s dijagnozom shizofrenije, S., 42 godine}

S obzirom da stručni djelatnici Centra za socijalnu skrb između ostaloga neposredno obavljaju i poslove skrbništva po službenoj dužnosti, ovdje je prikazana mogućnost primjene metode fraktalnog crteža i u takvim situacijama, na primjeru osobe kojoj sam imenovana skrbnikom.

S. je osoba s dijagnozom shizofrenije simplex i zbog bolesti se nalazi u mirovini. Moj je zadatak pratiti tijek njezina psihijatrijskog liječenja kontaktima s nadležnim psihijatrom i uvidima u liječničke nalaze, te prema potrebi donositi i druge odluke vezane uz tijek njezina liječenja.

Završila je Studij tekstilnog dizajna, iznimno je kreativna i društveno aktivna na način da je uključena u brojne aktivnosti poput slikanja, šivanja, posjećivanja izložaba; međutim, budući da zbog bolesti nije u mogućnosti raditi, ima potrebu za održavanjem dnevne strukture.

S obzirom na njezine interese i moguće dobrobiti primjene metode fraktalnog crteža, S. sam podučila toj metodi. Međutim, na samom početku imala je dosta poteškoća oko izrade crteža. Teško je slijedila upute, opetovano ponavljala iste pokrete i odustajala svaki put kada je trebalo uložiti veći trud. Kod bojenja nije imala dovoljno strpljenja ni motoričke sposobnosti lijepo obojiti crtež unutar polja, što se može vidjeti na prvom fraktalnom crtežu prikazanom na Slici 38.

S. je iskazala da se na dan, kada je izrađivala prvi crtež, osjećala lošije i usporeno zbog djelovanja psihofarmatika, te se na taj način može objasniti i dobiven rezultat tog crteža. U korekciji joj je preporučeno da radi na jačanju strukture i preciznosti putem linije i boje, osobito energičnijim bojenjem jačim pritiskom. Već na idućem crtežu prikazanom na Slici 39, vidljiv je značajan pomak, a redovitim trudom i radom usavršila je bojenje i postigla veću preciznost.

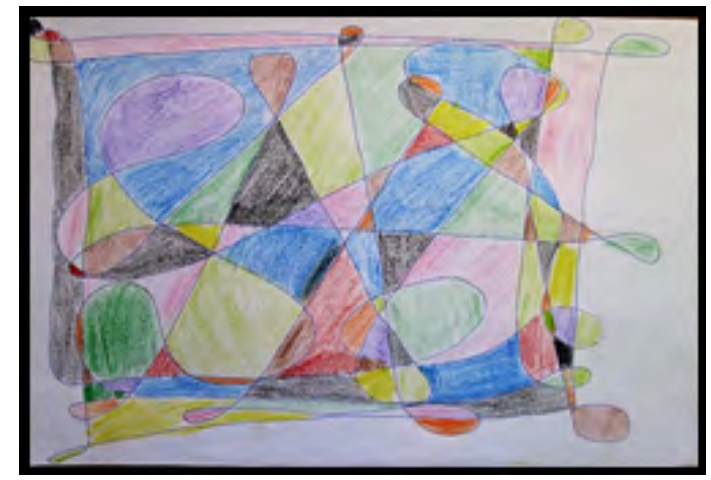

Slika 38. Prvi fraktalni crtež dijagnostički

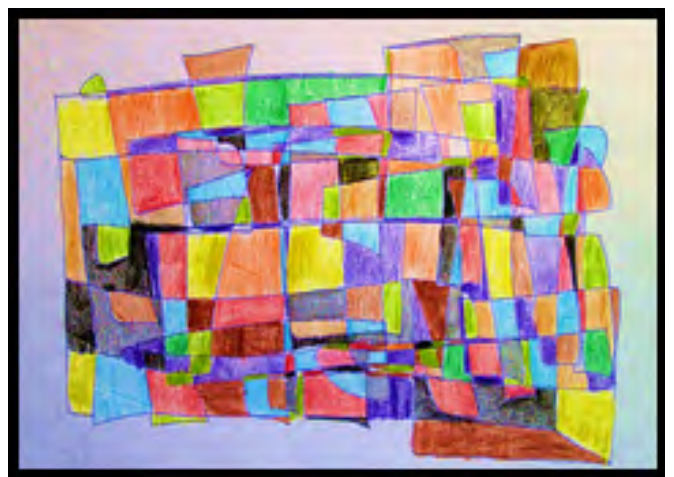

Slika 39. Drugi fraktalni crtež korekcijski

S obzirom da je S. sklona izradi modnih crteža, što je ujedno vezano i uz njezinu struku, usmjerila sam je na crtanje modnih fraktalnih crteža koji su je potpuno otvorili prema ovoj metodi i potaknuli njezinu kreativnost. Na crtežu 40 prikazan je njezin prvi jednostavniji modni fraktalni 
crtež, a na Slici 41 može se vidjeti njezino napredovanje i intenzivnijim bojenjem te složenijom formom s više detalja.

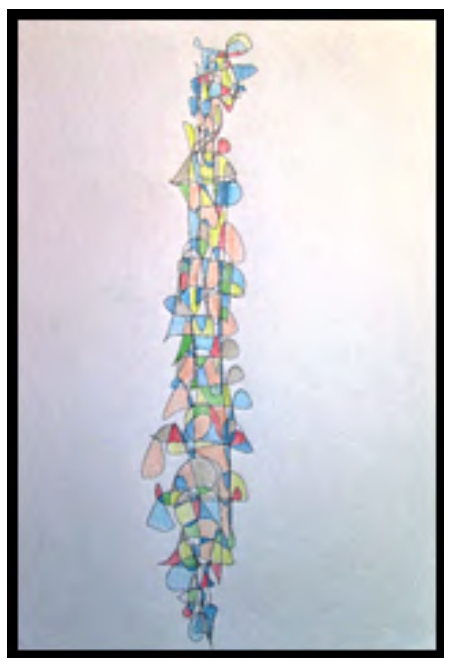

Slika 40. Prvi modni fraktal

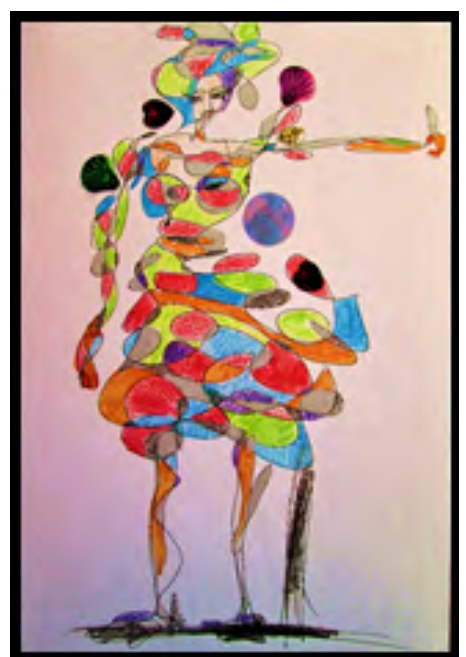

Slika 41. Složeniji crtež



Slika 42. Uvođenje tekstura

Tijekom rada S. je usmjeravana na sve veću preciznost bojenja te korištenje boja koje povoljno djeluju na funkcije mozga po fraktalnoj metodi, s obzirom na njezinu dijagnozu. Savjetovana je i uporaba grafičkih elemenata radi poboljšanja fokusa i koncentracije, koja se može vidjeti na crtežima prikazanima na slikama 42 i 43, na kojima je vidljiv i veliki napredak u tehnici crtanja i bojenja u odnosu na početne radove.

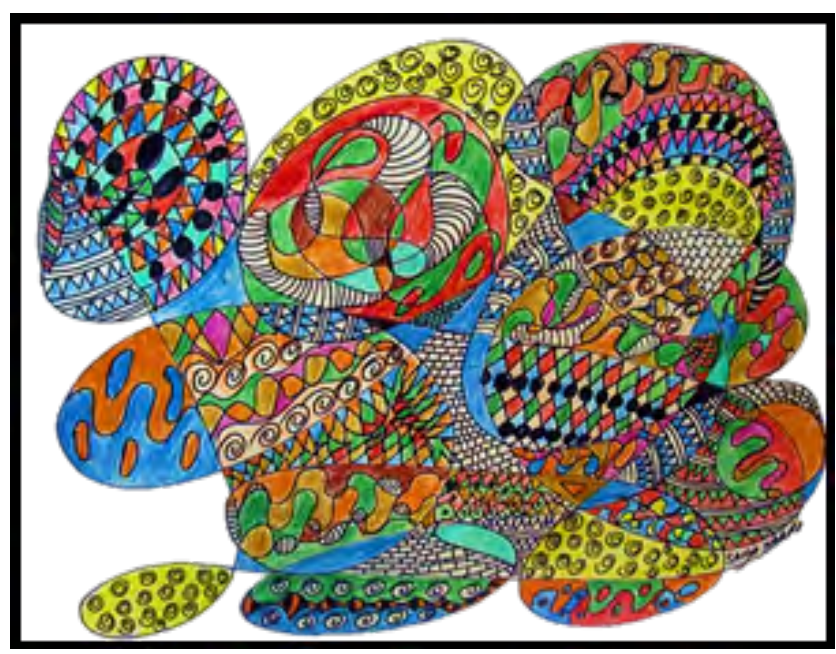

Slika 43. Fraktalni crtež s teksturom

Premda njezino zdravstveno stanje varira, zamijećeno je da je redovitim crtanjem fraktalnih crteža stabilnijeg stanja, aktivnija je nego ranije i zadovoljnija time što radi, čak je počela razmišljati i o honorarnom zapošljavanju, tako da slobodno mogu reći da je ova metoda podigla razinu njezina funkcioniranja i poboljšala kvalitetu života, a tome u prilog govore i njezini sljedeći komentari. 


\section{Komentari S. o njezinu iskustvu primjenom ove metode:}

— "Crtanje fraktalnih crteža povećalo je moju motivaciju za rad, kreativnost i poboljšalo moju motoriku tako da bolje i sigurnije crtam i otvorenim očima. Pomažu mi da se pokrenem i da redovito crtam makar par poteza."

- "Sviđa mi se ideja malih formata koja mi je pomogla da svakodnevno crtam fraktalne crteže i uspijevam ih završiti, što često ne mogu kada crtam velike formate.

— "Kada ne znam što bih radila crtam fraktale. Ti crteži pomažu mi da se smirim, budem bistrija u glavi."

— "Kada noću patim od nesanice, nacrtam jedan fraktalni crtež koji me opusti i pomogne mi da lakše zaspim."

\section{PRIKAZ SLUČAJA 5 - individualan rad s djevojkom s problemima u ponašanju, E., 18 godina}

Ovaj slučaj prikazuje individualan rad s djevojkom koja se nalazila u tretmanu Centra za socijalnu skrb kao počiniteljica kaznenog djela imovinskog karaktera. Odrasla je uz oca i starijeg brata, a majka je napustila obitelj.

Djevojka je stekla zvanje medicinske sestre. Pokazivala je sklonost konzumaciji psihoaktivnih tvari, najčešće marihuane. Uz dijagnozu shizofrenije bila je emotivno nestabilna te se nalazila u psihijatrijskom tretmanu. Imala je povijest nekoliko psihijatrijskih hospitalizacija zbog shizofrenih ispada potaknutih intoksikacijom psihoaktivnim sredstvima.

Nakon što sam je podučila ovoj metodi, izradila je dijagnostički crtež, a potom prema uputama i iduća dva crteža u kojima su postupno uvođeni elementi korekcije na način da se proširivao crtež, što je prikazano na Slikama 44, 45.

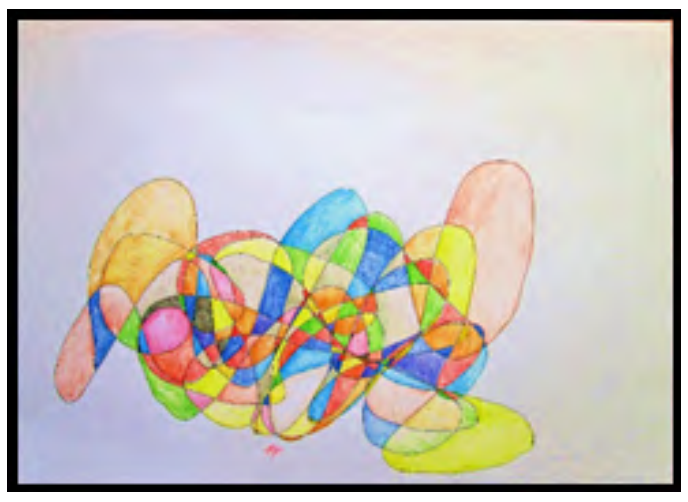

Slika 44. I. dijagnostički fraktalni crtež

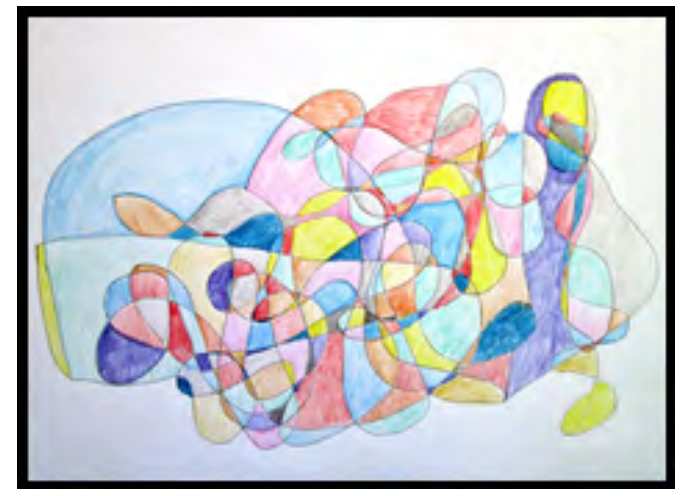

Slika 45. II. dijagnostički crtež

Djevojka je bila izrazito niska samopouzdanja, sklona odustajati od započetih aktivnosti, te je navedeni obrazac osvijestila svojim pristupom samom procesu izrade fraktalnih crteža. 


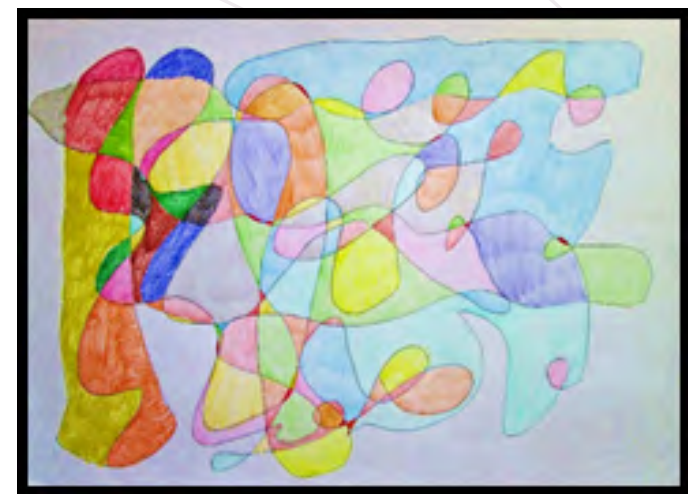

Slika 46. III. dijagnostički fraktalni crtež

Prilikom izrade trećeg crteža prikazanog na Slici 46, djevojka je priznala da je pod utjecajem marihuane i potaknula sam je da izradi crtež da bi sama uvidjela kakav utjecaj konzumacija psihoaktivnih tvari ima na nju. Tijekom crtanja djevojka je verbalizirala ljutnju na sebe jer je u recidivu, te je bojila uz manje truda, grubim i nervoznim potezima bojica, znatno različitim od načina na koji je izrađivala prethodne crteže. Lijeva strana crteža obojena jačim pritiskom započeta je u tom stanju, a ostatak crteža dovršila je nakon što se očistila od droge. Prilikom idućeg susreta i sama je bez puno mojih objašnjenja uvidjela razliku u svojem funkcioniranju i pristupu životu pod utjecajem marihuane, te shvatila prema načinu crtanja i bojenja da je djelovanje droge na nju bilo suprotno od opuštajućeg i umirujućeg kao što je prethodno vjerovala.

Nakon toga je ponovno odlučila apstinirati i uskoro pronašla željeni posao te je u narednom razdoblju uredno funkcionirala.

Na kraju tretmana nacrtala je fraktalni crtež podrške u obliku anđela prikazanog na Slici 47, koji je trebao simbolizirati podršku da bi ustrajala u apstinenciji i urednu funkcioniranju.

Premda je s nepovjerenjem pristupila tom zadatku, bila je oduševljena postignutim rezultatom.



Slika 47. Fraktalni crtež podrške - anđeo 
Komentari E. nakon primjene metode:

— "Osjećam da me crtanje i bojenje fraktalnog crteža smiruje. Tijekom crtanja barem dva sata ne mislim na probleme koji me opterećuju i ne radim gluposti koje bih inače radila. Smirena sam i osjećam se dobro jer sam napravila nešto korisno za sebe."

\section{Zaključak}

Metoda fraktalnog crteža zaintrigirala me prije svega iz razloga što je njezin fokus usmjeren na naše potencijale umjesto na nedostatke. Na taj se način djecu, koja ne vjeruju u sebe i svoje sposobnosti, putem primjene ove metode može ohrabriti i potaknuti da se usude istražiti i razviti svoje mogućnosti, učiniti da se osjete uspješnima i dobiju uvid u konkretne rezultate svojeg rada. $U$ današnje vrijeme, kada smo sa svih strana okruženi informacijama o našim nedostatcima i manama koje trebamo ispraviti, prava je blagodat prakticirati metodu koja nas uči vidjeti ljepotu u vlastitom i tuđem izričaju bez opterećenja nametnutim estetskim kriterijima.

Ova metoda govori jezikom srca tako poznatim djeci i samo uzimanje bojica u ruke vraća nas u doba bezbrižnosti i razigranosti djetinjstva, u svijet gdje je sve moguće. U tako opuštenu stanju lakše je učiniti odmak od svakodnevnih teškoća, predahnuti do momenta kada ćemo ponovno skupiti snage suočiti se aktivno s teškoćama na jedan nov i konstruktivan način. Primjenom metode stječemo nova znanja i vještine, a putovanjem kroz carstvo različitih boja i oblika upoznajemo sebe i svoje potencijale. Učeći nove vještine gradimo učinkovitije strategije i načine kretanja životom. Osim toga, čovjek u trenutku kada crta ulazi u jedno umirujuće stanje svijesti, gdje ne postoji ništa drugo osim crteža i fokusa na rad koji je zapravo zabavan. Taj proces možemo nazvati i jednim oblikom aktivne meditacije, prisutnosti u sadašnjem trenutku, koji je osobito pogodan za osobe koje imaju problem s održavanjem fokusa u klasičnim meditativnim tehnikama. Samo crtanje ne možemo smatrati svemogućim u smislu rješavanja problema bez našeg aktivna angažmana; međutim, sam fokus i namjera da poboljšamo naše opće stanje uz uložen trud u ovu metodu, svakako će pokrenuti naše skrivene resurse i približiti nas učinkovitijim načinima ostvarivanja željenih ciljeva.

Rad s djecom i mladima koji manifestiraju probleme u ponašanju osobito je izazovan, budući da se radi o ranjivoj skupini koja nerijetko ima poteškoće u prepoznavanju i verbalizaciji vlastitih emocionalnih stanja, kao i velike otpore prema korigiranju svojeg ponašanja. Primjena metode fraktalnog crteža pokazala se korisnom u radu s navedenom populacijom upravo iz razloga olakšavanja tog procesa, s obzirom da istu djeca nisu doživjela nametljivom već zabavnom i prirodnom te postupno učila prihvatiti pravila da bi korigirala loš osjećaj ili nepoželjno stanje. Osim toga, analizom pristupa crtežu i bojenju, dobivamo priliku mladim ljudima na slikovit i životan način pokazati kako se odnose prema sebi, svojem životu, poteškoćama, a bez rizika da razgovor o navedenome dožive kao osobnu kritiku jer, ipak, govorimo "samo" o njihovu crtežu. Ovdje je potrebno istaknuti i važnost primjene ove metode i zbog grafomotoričkih vježba, osobito ako pogledamo današnje trendove gdje tehnologija gotovo potpuno preuzima pisanje rukom, posebno imajući u vidu važnost tih vježba za razvoj i usklađivanje funkcija obiju moždanih polutaka. 
U današnje vrijeme kada je sveprisutan trend bojanki za odrasle, budući da su prepoznati pozitivni učinci takvih aktivnosti, ova metoda odlazi i korak dalje nudeći još jednu dimenziju razvijanja kreativnosti i dodatne stimulacije mozga uključujući i korištenje linije izuzev samog procesa bojenja.

Većina anketiranih sudionika radionica u prezentiranu Projektu, ali i ostalim prikazanim slučajevima individualnog i grupnog rada prema metodi fraktalnog crteža, prepoznala je potencijal ove metode za primjenu u svojem životu te su imali osobno iskustvo umirujućega i ugodna djelovanja procesa fraktalnog crtanja. Također, važno je istaknuti da je većina sudionika kao najzahtjevnijom ocijenila upravo radionicu na kojoj se radila korekcija putem linije i boje, što je na neki način i opravdano budući da korekcijski fraktalni crteži zahtijevaju ulaganje više truda i vremena da bi mozak lakše usvajao pravila, odnosno da bi došlo do usklađenja rada mozga i ruke, što se postiže redovitim treningom kao i kod bilo koje druge vještine.

Premda se ova metoda pokazala privlačnom za većinu osoba koje sam imala priliku podučavati, zamijetila sam da pojedinci nisu pokazivali interes za prakticiranje metode, kao što je ranije spomenuto, iz razloga što nisu skloni takvu načinu izražavanja, nelagode i straha od neuspjeha zbog izostanka kontrole nad rezultatima crtanja i mnogih drugih. $U$ takvim situacijama nije poželjno osobe koje su u otporu siliti na bilo koji način na sudjelovanje u fraktalnom crtanju, budući da pojedinci mogu intuitivno osjećati da bi ih izrada fraktalnih crteža mogla dovesti u kontakt $\mathrm{s}$ njihovim potisnutim, podsvjesnim sadržajima, odnosno pokrenuti u njima određene promjene na koje trenutno nisu spremni.

Izuzev umirujućeg učinka samog procesa crtanja, ove crteže smatram vrijednima jer posjeduju i dodatnu dimenziju harmonizirajućeg djelovanja prilikom izlaganja u prostoru, kao i nesvakidašnju ljepotu bez obzira na vještinu crtača. Osobito značajnima smatram fraktalne crteže podrške u kojima gradimo motiv koji simbolizira podršku u određenim ciljevima, a mogu se primijeniti i kao personaliziran poklon dragoj osobi poput čestitke s dobrim željama koje su iskazane kombinacijom linija i boja, što osobito privlači djecu.

$\mathrm{Na}$ temelju dosadašnjih iskustava u primjeni ove metode, većim djelom predstavljenih u ovom radu, mogla bih navesti sljedeće mogućnosti njezine primjene u socijalnopedagoškom radu:

— u individualnom i grupnom radu s djecom i mladima, ali i odraslim osobama radi prevencije rizičnih ponašanja, suzbijanja daljnjeg progrediranja neprihvatljiva ponašanja i funkcioniranja, razvijanja / jačanja percepcije, grafomotoričkih, kognitivnih i kreativnih sposobnosti, jačanja samopouzdanja, tolerancije, upornosti, dosljednosti, discipline, preveniranja stresa, korisnog provođenja slobodnog vremena

— podučavanjem djece i roditelja primjeni metode radi razvijanja kvalitetnijeg odnosa druženjem uz konstruktivnu i kreativnu interakciju

— podučavanjem stručnjaka primjeni metode radi preveniranja stresa, kao i primjene u radu s djecom

— organiziranjem izložaba dječjih radova, odnosno trajnim izlaganjem radova u institucijama u kojima borave djeca 
— provođenjem istraživanja da bi se utvrdili konkretni učinci i dobrobiti primjene ove metode u populaciji djece s problemima u ponašanju sustavnim radom s njima i praćenjem njihova stanja tijekom i nakon crtanja tijekom duljeg razdoblja

Prema svojem osobnom iskustvu mislim da fraktalni crteži osvajaju svojom jednostavnošću i snagom, povezuju ljude u onome što im je zajedničko, a opet uzimaju u obzir individualnost svakog pojedinca koja je značajna za cjelinu i obogaćuje je unikatnošću.

Ovim radom želim istaknuti da su djeca s problemima ponašanja i stručnjaci koji rade s njima željni novih znanja i vještina kojima mogu unaprijediti svoj život, ali i život zajednice, a taj cilj vrijedan je svakog ulaganja sustava. Ta neobična metoda osnažuje čovjeka prihvatiti odgovornost za svoj život i postati aktivnim sudionikom u njegovu stvaranju. Smatram da je to najveći dar koji možemo dati sebi i drugima i zbog toga ovaj rad posvećujem svima koji su vlastitim angažmanom pridonijeli širenju metode i radosti koju nosi njezina primjena.

\section{Literatura}

Darnold, M.P. (2016). Art therapy and Mindfulnesss for at-risk youth. Preuzeto s: alfredadler.edu/ sites/default/files/Darnold MP 2016.pdf. (19.06.2018.)

Dennison, P.E., Dennison, Gail, E. (2007). Brain Gym-priručnik za obitelj i edukatore. Buševec: Ostvarenje.

Glasser, W. (2004). Teorija izbora: nova psihologija osobne slobode. Zagreb: Alineja.

Kaudne, L., Koiv, K. (2015). Impact of Integrated Arts Therapy: An Intervention Program for Young Female Offenders in Correctional Institution. Preuzeto s: http://dx.doi.org/10.4236/ psych.2015.61001. (18.02.2019.)

Komov, A.E., Polujahtova, T.Z. (2014). Izvornik fraktalne mudrosti ili nov pogled na naše mogućnosti. Zagreb: Puni potencijal.

Kosec, M. (2016). Radionica crtanja fraktala, radna skripta. Zagreb: Puni potencijal.

Kosec M., Muck D. (2018). Put ljubavi-put k sebi-Metodom fraktalnog crteža do slobode srca. Zagreb: Puni potencijal.

Orlović, I. (2019). Što je neuroznanost. Preuzeto s: https//hr.onlinemedicineinfo.com/what-is-neuroscience-79386). (19.02.2019.)

Polujahtova, T.Z. (2016). Edukacija: Fraktali u psihoterapiji, Zagreb.

Škrbina, D. (2013). Art terapija i kreativnost-multidimenzionalni pristup u odgoju, obrazovanju, dijagnostici i terapiji. Zagreb: Veble commerce.

Šprljan Szivo, T. (2017). Što je grafomotorika, kako se razvija i kako ju poboljšati. Preuzeto s: https:// www.maminsvijet.hr/briga-o-djeci/vrtic-i-jaslice/grafomotorika-sto-je-kako-se-razvija-i-kako-ju-poboljsati/. (19.02.2019.)

Weiner, E.T. (2012). A Mindful art program: Using Mindfulness and Focusing-oriented art therapy with children and adolescents to decrease stress and increase self-compassion. Preuzeto s: www.focusing.org/docs/arts_therapy/Weiner-(2012)-A-Mindful-Art-Program-Using-Mindfulness.pdf. (19.06.2018.) 
Valentina Hundrić: Primjena metode fraktalnog crteža u socijalnopedagoškom radu

Izvori fotografija:

Andrijić, Z. (2005). Zanimljiva znanost:Fraktali, Plavi planet-magazin svjesnosti, br. 4, str.40.

www.crtanje -fraktala.com/o-crtanju-fraktala (05.01.2017.)

https//wordpress.com/2017/02/20/fraktalna-geometrija-matematika-u-službi-majke-prirode (05.01.2017.)

https://medatrio.com/parkinsons-sinapsi-neuroni (05.01.2017.)

Hundrić, V. (2017). Osobni fraktalni ciklus. 


\title{
Application of the fractal pattern drawing method in socio-pedagogical work
}

\begin{abstract}
Summary
In this paper, the aim is to present the creative aspect of socio-pedagogical work through the possibilities of applying the Fractal Pattern Drawing Method in Working with Children and Young People with Behavioral Problems as well as with the experts working with them, primarily through the presentation of the "Lines and Colors Reveal Me" project intended for children and young people in institutional treatment and educators working with them, with a main goal to prevent risky activities and strengthening capacities for easier coping with stressful situations. During the project, 80 participants, Children and Young People with Behavioral Problems as well as the experts working with them, were educated in using this method, most of whom through self-rating method verbalized positive effects in its practical applying, such as being in good mood and feeling relaxed.

The Fractal Pattern Drawing Method is an innovative and creative method based on the principles of art therapy, brain gym, chromotherapy, graphomotor exercises and neuroscience concepts, which is significant because of its simplicity, relaxing effect on the drawers, and the effects on the development and strengthening of cognitive functions or attention, concentration, creativity, self-confidence, motivation to work.

The method is based on the fact of the connection between the motor of the hand and the human psycho-physiological states and has diagnostic and therapeutic potential.

The technique is very simple and consists of the spontaneous drawing of an unbroken line with closed eyes and the coloring of the fields formed by the line interlinking. The method is easy to apply in individual or group work, unrelated to age or prior drawing experience.
\end{abstract}

Key words: fractal drawing, creative and cognitive potential development, risk behavior, prevention 